\title{
Genomics-assisted breeding in four major pulse crops of developing countries: present status and prospects
}

\author{
Abhishek Bohra • Manish K. Pandey $\cdot$ Uday C. Jha $\cdot$ \\ Balwant Singh • Indra P. Singh • Dibendu Datta • \\ Sushil K. Chaturvedi · N. Nadarajan • Rajeev K. Varshney
}

Received: 21 November 2013 / Accepted: 17 March 2014 / Published online: 8 April 2014

(C) The Author(s) 2014. This article is published with open access at Springerlink.com

\begin{abstract}
Key message Given recent advances in pulse molecular biology, genomics-driven breeding has emerged as a promising approach to address the issues of limited genetic gain and low productivity in various pulse crops. Abstract The global population is continuously increasing and is expected to reach nine billion by 2050 . This huge population pressure will lead to severe shortage of food, natural resources and arable land. Such an alarming situation is most likely to arise in developing countries due to increase in the proportion of people suffering from protein and micronutrient malnutrition. Pulses being a primary and affordable source of proteins and minerals play a key role in alleviating the protein calorie malnutrition, micronutrient deficiencies and other undernourishment-related issues. Additionally, pulses are a vital source of livelihood generation for millions of resource-poor farmers practising agriculture in the semi-arid and sub-tropical regions. Limited
\end{abstract}

Communicated by A. J. Bervillé.

A. Bohra $(\varangle) \cdot$ U. C. Jha $~ I$. P. Singh $\cdot$ D. Datta

S. K. Chaturvedi $\cdot$ N. Nadarajan

Indian Institute of Pulses Research (IIPR), Kanpur 208024, India

e-mail: abhi.omics@gmail.com

M. K. Pandey $\cdot$ R. K. Varshney $(\bowtie)$

International Crops Research Institute for the Semi-Arid Tropics (ICRISAT), Hyderabad 502324, India

e-mail: r.k.varshney@cgiar.org

B. Singh

National Research Centre on Plant Biotechnology (NRCPB),

New Delhi 110012, India

R. K. Varshney

The University of Western Australia (UWA), Crawley 6009, Australia success achieved through conventional breeding so far in most of the pulse crops will not be enough to feed the ever increasing population. In this context, genomics-assisted breeding (GAB) holds promise in enhancing the genetic gains. Though pulses have long been considered as orphan crops, recent advances in the area of pulse genomics are noteworthy, e.g. discovery of genome-wide genetic markers, high-throughput genotyping and sequencing platforms, high-density genetic linkage/QTL maps and, more importantly, the availability of whole-genome sequence. With genome sequence in hand, there is a great scope to apply genome-wide methods for trait mapping using association studies and to choose desirable genotypes via genomic selection. It is anticipated that GAB will speed up the progress of genetic improvement of pulses, leading to the rapid development of cultivars with higher yield, enhanced stress tolerance and wider adaptability.

\section{Introduction}

The Fabaceae/Leguminosae or legume family with $~ 20,000$ species is the third largest family in the plant kingdom and second most important after Gramineae or Poaceae as mainstays for human food/protein security (Cannon et al. 2009; Gepts et al. 2005; Weeden 2007; Young et al. 2003). Legumes are endowed with the unique property of biologically fixing atmospheric nitrogen via symbiosis, making them an integral component of sustainable agricultural production systems (Zhu et al. 2005). In the Fabaceae, grain legumes or pulses are particularly important in supplying adequate quantity of lysine-rich protein to humans, thereby complementing the conventional cereal-based carbohydrate-rich diets, which are otherwise deficient in lysine and tryptophan (Broughton et al. 2003; Ufaz and 
Galili 2008). Additionally, pulses are potential sources of several essential minerals, vitamins and secondary metabolites like isoflavonoids in human diets (Cannon et al. 2009). Concerning protein deficiency, it is important to emphasize that globally over one billion people are currently suffering from protein and micronutrient malnutrition (Godfray et al. 2010). In this context, pulses by virtue of their high protein, vitamin and mineral content play a crucial role in alleviating micronutrient deficiencies, undernourishment or protein calorie malnutrition (PCM), especially in the lessdeveloped countries (Broughton et al. 2003).

FAO categorizes only those legumes as pulses which are harvested exclusively for grain purpose, thereby recognizing a total of 11 pulse crops (http://faostat.fao.org/; Akibode and Maredia 2011). In terms of worldwide pulse production, a total of 70.41 million tons $(\mathrm{m} \mathrm{t})$ are harvested annually from 77.5 million $(\mathrm{m})$ ha area with a productivity of $907 \mathrm{~kg} / \mathrm{ha}$ (FAOSTAT 2012). Almost $90 \%$ of the global pulse production $(62.98 \mathrm{~m} \mathrm{t})$ is shared by major pulse crops, viz. dry beans (mainly common bean), chickpea, dry peas (pea), cowpea, pigeonpea, lentil and faba bean. Based on their adaptability to tropical and temperate agro-climatic conditions, these pulse crops can be further categorized into two distinct groups, i.e. (1) warm season crops (common bean, pigeonpea and cowpea) and (2) cool season crops (pea, chickpea, lentil and faba bean) (Cannon et al. 2009; Young et al. 2003; Zhu et al. 2005). Interestingly, chickpea, pea and lentil are among the founder grain crops, which experienced domestication early in pre-history (c. 11,000 years ago), and these paved the way for establishment of modern agriculture (Zohary and Hopf 2000). The pulse crops have always been a key contributor to maintaining sustainability of the farming systems in the semi-arid and sub-tropical world and in generating livelihood and food security to millions of resource-poor people inhabiting these regions (Broughton et al. 2003).

Owing to their immense agricultural value, exhaustive research has been done for pulse improvement through conventional breeding, resulting in the development and release of several high-yielding varieties (Gaur et al. 2012; Pérez de la Vega et al. 2011; Saxena 2008; Singh 2005; Torres et al. 2011), followed by an increase in the global area under pulses from 64 to $77.5 \mathrm{~m}$ ha over the last 50 years (FAOSTAT 2012). With respect to productivity, however, appreciable gains have not been materialized so far in any of the major pulse crops (Fig. 1). The productivity of major pulse crops remains dismally low, around 1,000 kg/ha, and large gap exists between their potential and actual yields (FAOSTAT 2012; Varshney et al. 2013a). In this context, integrating genomic tools with conventional breeding methods holds the key to accelerate the progress of crop improvement. Unlike cereals like wheat and barley (which were domesticated

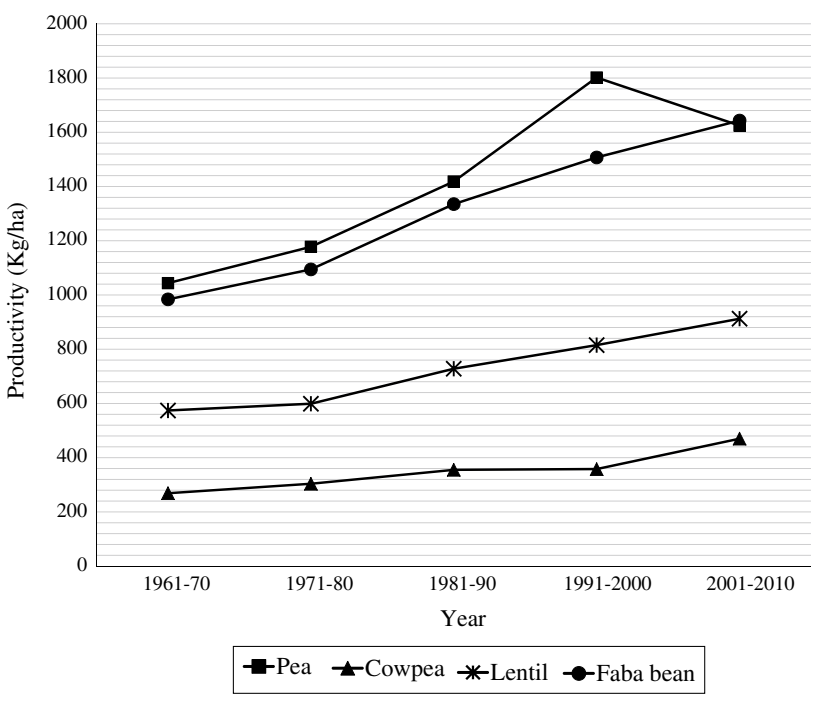

Fig. 1 Global trends in productivity of four major pulse crops. The figure illustrates trends in productivity of major pulse crops witnessed over the last five decades

almost at the same time as pulses), limited efforts have been directed towards undertaking molecular breeding or more appropriately genomics-assisted breeding (GAB) of pulse crops (Muchero et al. 2009a; Muehlbauer et al. 2006; Timko et al. 2007; Varshney et al. 2010). One likely reason is the limited attention of the international research community to these pulse crops. As a result, there has been a dearth of prerequisite genomic tools to commence GAB at a larger level (Varshney et al. 2009a). These crops, therefore, are often referred to as "orphan crops". Nevertheless, in some pulse crops, large-scale genomic tools, technologies and platforms have become available in recent years (Gaur et al. 2012; Gepts et al. 2008; Kelly et al. 2003; Muehlbauer et al. 2006; Rubiales et al. 2011; Varshney et al. 2013a), thereby opening up new avenues for practising GAB. This is a highly opportune time for reframing our breeding strategies, allowing judicious and routine use of genomic tools for genetic enhancement of modern cultivars as well as diversification of the primary gene pool through introduction of desirable alien alleles from crop wild relatives (CWRs). Advances in genomics and molecular breeding have been discussed in details for chickpea and pigeonpea in some recent reviews (Varshney et al. 2013a). However, not much information is available about recent developments in case of other pulse crops. In consideration of the above, this review summarizes the production scenario and constraints, the available genomic resources and their downstream applications as well as prospects for $\mathrm{GAB}$ in four selected pulse crops, i.e. cowpea (Vigna unguiculata (L.) Walp.), pea (Pisum sativum L.), lentil (Lens culinaris Medik.) and faba bean (Vicia faba L.). 


\section{Global production scenario and major yield constraints}

Although there are several warm and cool season pulse crops that make important portion of diets of the poor in developing countries, four major pulse crops, namely, cowpea, pea, lentil and faba bean, have been included here for discussion.

\section{Cowpea}

Cowpea (Vigna unguiculata (L.) Walp.), also referred to as black-eyed pea, crowder pea or lobia, is a self-pollinating diploid $(2 n=2 x=22)$ species with an estimated genome size of $620 \mathrm{Mb}$ (Chen et al. 2007; Singh 2005). It is an important warm season grain legume cultivated in $\sim 30$ countries (Singh 2005). Interestingly, more than $80 \%$ of dry cowpea produce comes from three countries (Niger, Nigeria and Burkina Faso) of West Africa that cover nearly $83 \%$ of the global cowpea area (FAOSTAT 2012; Popelka et al. 2006). Therefore, cowpea remains the primary source of income for small-scale farmers practising agriculture in dry Savannah of sub-Saharan Africa. Furthermore, cowpea also provides a cheap and highly nutritious feed for livestock in tropical West and Central Africa (Kamara et al. 2012). Asparagus bean (also known as snake bean or yardlong bean) is another cultivar group (cv.-gr. sesquipedalis) of cowpea that reflects remarkable morphological variations from African cowpea (cv.-gr. unguiculata) in plant architecture, growth habit and various pod-/seed-related characters (Kongjaimun et al. 2013; Singh 2005; Timko et al. 2007; Xu et al. 2013). Asparagus bean is grown primarily in Southeast and East Asia for its very long and tender pods, which are harvested at the immature stage and considered a highly nutritious vegetable (Xu et al. 2010, 2011a, b, 2012a).

Globally, cowpea has shown an increasing trend in its cultivation area from $2.41 \mathrm{~m}$ ha to $10.68 \mathrm{~m}$ ha over the last five decades (FAOSTAT 2012). The miserably low productivity of cowpea $(\sim 470 \mathrm{~kg} / \mathrm{ha})$ is largely attributable to a variety of constraints that prevail in cowpea-growing areas including diseases such as bacterial blight (Xanthomonas axonopodis pv. vignicola (Burkh.) Dye), rust (Uromyces phaseoli var. vignae Barclay), Sphaceloma scab (Elsinoe phaseoli Jenkins) and leaf spot (Septoria vignicola Rao), and insects/pests such as legume flower thrips (Megalurothrips sjostedti Trybom), pod borer (Maruca vitrata Fabricius) and storage weevil (Callosobruchus maculatus Fabricius) (Singh 2005). Apart from the above-mentioned constraints, instances of severe parasitism by weeds (Striga gesnerioides (Willd.) Vatke and Alectra vogelii (L.) Benth) resulting in $85-100 \%$ loss have also been observed in cowpea (Kamara et al. 2012). The inherent tolerance to drought, heat and poor soil fertility makes cowpea an attractive crop for low-input farming systems in the Sudanian and Sahelian semi-arid regions of Africa (Hall et al. 2003; Hall 2004; Muchero et al. 2009a; Popelka et al. 2006). However, despite its high tolerance to drought, considerable reduction in cowpea yield has been reported due to prolonged drought periods in sub-Saharan Africa (Hall et al. 2003; Hall 2004; Muchero et al. 2009b).

Pea

Pea (Pisum sativum L.) is a self-pollinating crop with $4,063 \mathrm{Mb}$ genome organized into seven pairs of homologous chromosomes $(2 n=2 x=14)$ (Arumuganathan and Earle 1991). Worldwide, a total of $9.86 \mathrm{~m}$ t of dry peas is harvested annually with exceptionally high productivity $(1,558 \mathrm{~kg} / \mathrm{ha})$. The three major pea producers, i.e. Russian Federation, Canada and China, collectively contribute around $56 \%(5.57 \mathrm{~m} \mathrm{t})$ and $54 \%$ (3.39 $\mathrm{m} \mathrm{ha})$ to the global production and area, respectively (FAOSTAT 2012). Interestingly, no major antinutritional factor (ANF) has been reported in pea seeds, thereby making dry pea seeds a highquality source for livestock feed and human consumption. Quite noticeably, almost half of the dry pea seeds harvested globally are used to feed livestock (Rubiales et al. 2011).

Among several biotic stresses affecting pea yields, Fusarium wilt (F. oxysporum f. sp. pisi (van Hall) Snyd. and Hans.), Ascochyta blight, a complex fungal disease caused by Mycosphaerella pinodes (Berk. and Blox.) Vestergr., Phoma medicaginis Malbr. and Roum. var. pinodella and Ascochyta pisi Lib.), root rot (Aphanomyces euteiches Drech.) and powdery mildew (Erysiphe pisi DC) are the most devastating diseases causing significant losses (Dixon 1987; Rubiales et al. 2011; Timmerman-Vaughan et al. 2002; Xue et al. 1997). In addition, one insect pest that has also emerged as a serious threat to pea production is pea aphid, Acyrthosiphon pisum (Harris), causing complete crop failure under conditions of severe infestations (Wale 2002).

Lentil

Lentil (Lens culinaris Medik.) is a self-pollinated diploid $(2 n=2 x=14)$ crop with a large genome size $(4,063 \mathrm{Mb})$ (Arumuganathan and Earle 1991). From the standpoint of global production, lentil stands fifth with $4.55 \mathrm{~m} \mathrm{t}$ being produced annually from an area of $4.24 \mathrm{~m}$ ha (FAOSTAT 2012). Major lentil-growing countries are India, Australia, Canada and Turkey, together producing more than $73 \%$ of the world's lentil (FAOSTAT 2012). Due to higher protein content and better digestibility, lentil contributes to nutritional and food security for the people in the northern temperate, Mediterranean and sub-tropical savannah regions (Sharpe et al. 2013). 
Various fungal diseases affecting lentil yield substantially have been reported, which include Ascochyta blight (A. lentis Vassilievsky), Fusarium wilt (F. oxysporum f.sp. lentis Vasd. and Srin.), anthracnose (C. truncatum (Schwein.) Andrus and Moore), blight (Stemphylium botryosum Wallr.), rust (Uromyces viciae-fabae Pers.), collar rot (Sclerotiun rolfsii Sacc.), root rot (Rhizoctonia solani Kühn), dry root rot (R. bataticola Taub.) and white mould (Sclerotinia sclerotiorum (Lib.) de Bary) (Ford et al. 2007; Muehlbauer et al. 2006; Pérez de la Vega et al. 2011). Aside from biotic factors, lentil production is also vulnerable to temperature extremities including cold and heat stresses and others like drought and salinity (Muehlbauer et al. 2006).

\section{Faba bean}

Faba bean (Vicia faba L.), also known as broad bean or horse bean, has six pairs of chromosomes and 13,000 Mb genome representing one of the largest genomes among legumes that is almost three times greater than pea and lentil (Cruz-Izquierdo et al. 2012; Yang et al. 2012; Young et al. 2003). It is cultivated in about 60 countries covering a total of $2.43 \mathrm{~m}$ ha area with an annual production of $4 \mathrm{~m} \mathrm{t}$ (FAOSTAT 2012). Worldwide, China (0.95 m ha), Ethiopia (0.45 m ha), Morocco (0.18 $\mathrm{m}$ ha) and Australia (0.16 m ha) are the main faba bean-growing countries. China alone produces $35 \%(1.4 \mathrm{~m} \mathrm{t})$ of the global dry faba beans followed by Ethiopia $(0.71 \mathrm{~m} \mathrm{t})$ and Australia $(0.42 \mathrm{~m} \mathrm{t})$. It is a dualpurpose crop, which not only provides inexpensive proteins for human consumption (particularly in western Asia and northern Africa), but also serves as a prime livestock feed in Europe and Australia (Alghamdi et al. 2012; Ellwood et al. 2008; Torres et al. 2006, 2011; Zeid et al. 2009).

Notwithstanding the higher productivity of faba bean $(1,666 \mathrm{~kg} / \mathrm{ha})$, the global area under faba bean cultivation has declined over the last five decades (FAOSTAT 2012). Faba bean production is constrained by a number of biotic factors including fungal, bacterial and viral diseases, nematodes and pests (Gnanasambandam et al. 2012). Amongst various diseases, rust (Uromyces viciae-fabae (Pers.) J. Schröt.), chocolate spot (Botrytis fabae Stard.), Ascochyta blight (A. fabae Sperg.) and downy mildew (Peronospora viciae (Berk.) Caspary) are of considerable economic importance (Cubero and Nadal 2005; Gnanasambandam et al. 2012; Torres et al. 2006, 2011). Apart from the diseases mentioned above, zonate spot (Cercospora zonata Wint.), roo rot (F. solani Mart.) and blister disease (Olpidium viciae Kusano) also cause significant yield loss, particularly in China (Li-Juan et al. 1993; Saxena et al. 1993). In addition, the viral diseases that negatively affect faba bean production involve broad bean mosaic virus (BBMV), broad bean wilt virus (BBMV), turnip mosaic virus (TuMV), soybean mosaic virus (SMV) and cucumber mosaic virus (CMV) (Saxena et al. 1993). Among important insect pests, faba bean beetle (Bruchus rufimanus Boheman), medic aphid (Aphis medicaginis Koch and Myzus persicae) and root nodule weevil (Sitona amurensis Faust and $S$. lineatus $\mathrm{L}$.) are the other damaging agents (Bardner 1983; Cubero and Nadal 2005; Li-Juan et al. 1993; Saxena et al. 1993). Moreover, frequent occurrence of a parasitic weed broomrape (Orobanche crenata Forks) often presents a great menace to faba bean cultivation in the Mediterranean region, North Africa and the Middle East (Díaz-Ruiz et al. 2009a; Rubiales and Fernández-Aparicio 2012; Torres et al. 2010) and several reports have documented yield loss up to $80 \%$ (Gressel et al. 2004) or even complete crop failure (Sauerborn and Saxena 1986).

Besides biotic constraints, faba bean also suffers from drought and cold stresses, frost injury and presence of ANFs in seeds (Arbaoui et al. 2008; Torres et al. 2011). Therefore, to stabilize faba bean yield, development of genotypes exhibiting resistance to the above-mentioned biotic and abiotic stresses has always been a prime objective in faba bean breeding. Moreover, the partial cross-pollinating nature and existence of cytoplasmic genetic male sterility (CGMS) have steered faba bean breeding towards development of CGMS-based hybrids for exploitation of heterosis and enhancement of productivity (Bond 1989; Link et al. 1996, 1997).

\section{Genomic resources}

Concerning pulse genomics, a rapid progress has been witnessed over the last 10 years generating a plethora of genomic tools for their extensive use in pulse improvement programmes. These resources include (1) different kinds of bacterial artificial chromosome (BAC)-derived resources like BAC libraries, BAC-end sequences (BESs), BAC-associated simple sequence repeat (SSR) markers (BES-SSRs) and physical maps; (2) genome-wide distributed molecular markers and automated genotyping platforms; and (3) the transcriptome and whole-genome assemblies.

\section{BAC-based resources}

BAC libraries are valuable tools for facilitating various genetic applications such as DNA marker development, gene/QTL cloning, construction of physical map and BACto-BAC genome sequencing (Farrar and Donnison 2007). In pulses, several BAC/BIBAC libraries were established, providing extensive genome coverage in the respective crops, viz. cowpea $(\sim 9 \times)$ and pea $(\sim 2.2 \times)$ (Coyne et al. 2007; Kami et al. 2006). To date, however, no BAC libraries have been reported for lentil and faba bean. BAC libraries have been used for developing physical map and 
assembling the genome sequences. In this context, BACs are subjected to fingerprinting and these fingerprints are then used as seeds for the development of genome-wide physical maps and in the determination of minimum tiling path (MTP) for assembling the whole-genome sequence (Venter et al. 1996). A high-quality BAC-based physical map is now available for cowpea (790 contigs and 2,535 singletons, http://phymap.ucdavis.edu/cowpea/).

To enhance the accuracy of physical maps or assembling the sequences of BACs in the whole-genome sequencing, selected or entire set of BACs are also used for generating BESs. Additionally, the utility of these BESs in large-scale marker development has also been demonstrated through in silico SSR mining in cowpea (Xu et al. 2011a). These BESassociated markers such as BES-SSRs represent the potential anchoring points for integrating genome-wide physical maps with high-density genetic maps (Córdoba et al. 2010).

Genome-wide distributed molecular markers

Starting from the introduction of hybridization based markers, viz. restriction fragment length polymorphism (RFLP), consistent improvements have been made in the area of DNA marker development and genotyping (see Bohra 2013). To this end, the traditional DNA marker technologies are being increasingly replaced by next-generation sequencing (NGS)-based high-throughput (HTP) discovery of DNA markers, especially single nucleotide polymorphisms (SNPs) (Varshney et al. 2009b). Further, on account of their amenability to automated genotyping platforms, SNPs have emerged as the preferred markers for next generation, substituting the earlier hybridization as well as polymerase chain reaction (PCR)-based assays (Varshney et al. 2009b). Through in silico mining of expressed sequence tags (ESTs), transcriptomes and whole-genome sequence, a large number of SSRs and SNPs have recently been detected in pulse crops (Table 1). For example, massive-scale SSR markers including 2,393 and 28,503 SSRs were developed in pea and faba bean, respectively, using Roche 454-FLX sequencing (Kaur et al. 2011; Yang et al. 2012). Likewise, thousands of SNP markers were identified in pea $(50,000)$ and lentil $(44,879)$ using NGS technologies such as Roche 454-FLX and Illumina Genome Analyzer (GA) (Sharpe et al. 2013; Sindhu et al. 2013).

Interestingly, the discovery of high-density SNP markers is complemented with the establishment of ultra HTP genotyping assays like Illumina GoldenGate (GG) and Infinium assays, which are able to accommodate up to 3,000 and 4 million SNPs, respectively (Deschamps et al. 2012). Informative SNPs were chosen for designing robust GG assays and as a result 768-/1,536-SNPs based GG platforms have become available in cowpea (Lucas et al. 2011; Muchero et al. 2009a, 2013), pea (Duarte et al. 2014;
Leonforte et al. 2013; Sindhu et al. 2013), lentil (Kaur et al. 2013; Sharpe et al. 2013) and faba bean (Kaur et al. 2014). Further, increasing number of re-sequencing database in coming days will allow identification of more SNPs and, consequently, HTP cost-effective genotyping assays using only informative SNPs will become available in all pulse crops.

Due to major shortcomings of GG and Infinium assays including cost-prohibitive designing and low flexibility, some customized SNP detection systems like competitive allele-specific PCR (KASPar) have been introduced to incorporate small to moderate number of SNPs for specific applications (Hiremath et al. 2012; Khera et al. 2013; Kumar et al. 2012; Saxena et al. 2012). Given the flexibility mentioned above, the KASPar assay was used for typing SNPs in asparagus bean (Xu et al. 2012a), lentil (Fedoruk et al. 2013; Sharpe et al. 2013) and faba bean (Cottage et al. 2012). Similarly, another custom-designed Illumina Veracode assay was employed for genotyping a set of 384 SNP markers in pea (Deulvot et al. 2010). Utilization of such automated genotyping systems not only enhances the speed of genotyping, but also ensures better accuracies in SNP typing. Apart from SNPs, diversity arrays technology (DArT) is another second-generation automated platform that enables genotyping of hundreds to thousands of genome-wide DNA markers with great precision. Successful implementation of DArT system has been reported in several pulse crops including chickpea and common bean for genetic linkage mapping and genetic diversity estimation (Briñez et al. 2012; Thudi et al. 2011). However, among the pulse crops presented here, to our knowledge DArT markers have not been applied so far.

Transcriptome and genome assemblies

Transcriptome assemblies are excellent genomic resources to capture the gene space for both basic and applied studies. Transcriptome assemblies facilitate detailed comparative analyses across different genera and discovery of functionally relevant markers (FMs), especially EST-SSR, SNP, intron-targeted primer (ITP) or intron spanning region (ISR) markers (Agarwal et al. 2012; Kudapa et al. 2012). More importantly, in case of crops like pea, lentil and faba bean with large and poorly characterized genomes, comprehensive transcriptome assemblies offer a means to directly access the gene space and causative functional polymorphisms, thus yielding valuable insights about the genome organization.

Initially, Sanger sequencing of c-DNA libraries generated transcriptomics resources such as ESTs for various crop species. For instance, a total of 183,118 ESTs were recovered through sequencing of nine c-DNA libraries in cowpea (Muchero et al. 2009a). Recently, transcriptome/ 


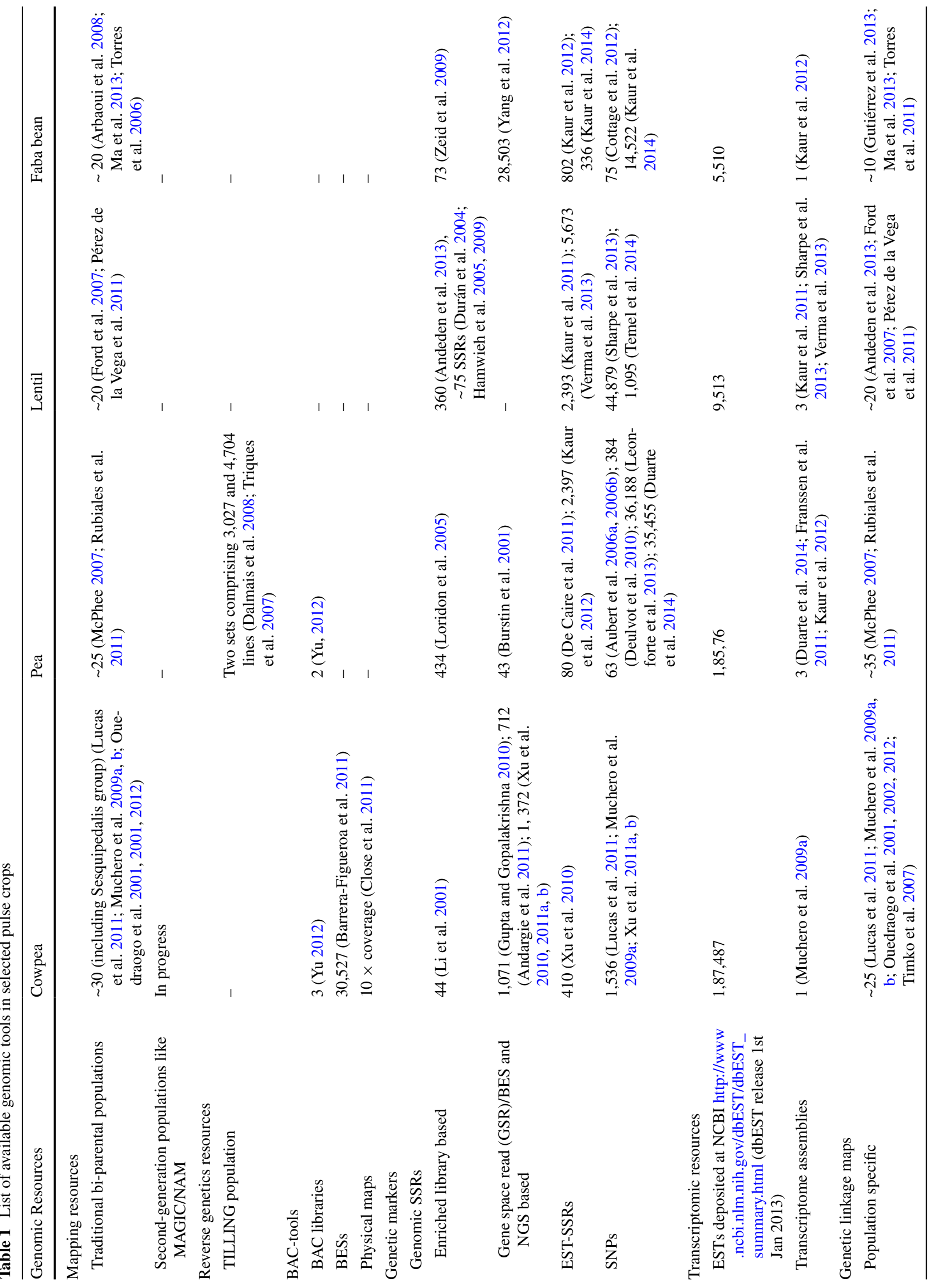


cDNA library sequencing using 454 GS-FLX Titanium (generating longer reads) and Illumina GA/GAIIx systems (comparatively shorter reads) has appeared as a potential alternative to leverage the genomic resource repertoire. Deep transcriptome sequencing has been performed in pea (Duarte et al. 2014; Franssen et al. 2011; Kaur et al. 2012), lentil (Sharpe et al. 2013; Verma et al. 2013) and faba bean (Kaur et al. 2012). As a result of this HTP sequencing, massive transcriptomic data were obtained in the form of high-quality sequence reads in the selected pulse crops, viz. pea (720,324 reads), lentil ( 847,824 reads) and faba bean $(304,680)$, and the transcriptome assemblies consisted of $70,682,84,074$ and 60,440 unigenes, respectively.

Based on the different approaches chosen for assembly of NGS reads, various kinds of transcriptome assemblies, viz. de novo, reference based and hybrid are being established in these pulse crops (Agarwal et al. 2012; Kudapa et al. 2012). The immense potential of NGS was also explored for whole-genome transcript profiling in faba bean, and NGS in combination with super serial analysis of gene expression (SAGE) led to the generation of 1,313,009 tags shedding new light on the transcriptional changes that take place during faba bean-Ascochyta fabae interaction (Madrid et al. 2013). Moreover, from functional genomics concerns, faba bean is particularly important as it has served as an excellent system for understanding the kinetics of stomatal movements in plants (Chen et al. 2004; Dietrich et al. 2001; Gao et al. 2005; Hanstein and Felle 2002). In addition to transcriptome, low-depth 454 sequencing was successfully utilized to uncover the repetitive DNA in the pea genome, which enabled a genome-wide characterization of the major repeat families and comparison of repeat composition with other legume species including soybean and Medicago (Macas et al. 2007).

On account of their shorter sequence reads and higher error rates (as compared to Sanger sequencing), NGS methods were initially considered suitable for re-sequencing of genotypes where a high-quality reference genome sequence was available (Imelfort and Edwards 2009; Varshney et al. 2009 b). With continuous refinements being made in computational algorithms that are used for assembly and alignment, NGS was also applied to de novo whole-genome sequencing especially in the crops with moderate-sized genomes and even in the absence of physical maps (Varshney et al. 2011). In contrast to the BAC by BAC method, which is very tedious involving construction of BAC libraries, sequencing of BACs, development of a physical map and the determination of MTP, the current de novo genome assembly using whole-genome shotgun (WGS) approach is straightforward, cost-effective and time saving (Imelfort and Edwards 2009; Venter et al. 1996).

In addition to model legume species like Medicago truncatula (Young et al. 2011), Lotus japonicus 
(http://www.kazusa.or.jp/lotus/index.html), whole/draft genome sequence has become available for soybean (Schmutz et al. 2010), pigeonpea (Varshney et al. 2011) and chickpea (Varshney et al. 2013b). More recently, $52 \%$ (598 Mb) genome has been assembled for lupin (Yang et al. 2013). Among pulses selected for discussion here, assembling the gene space in cowpea is underway (Tim Close, personal communication). Similarly, efforts have been initiated to sequence genomes of pea and lentil. In case of lentil, a draft $(23 \times)$ of the genome assembly has recently been generated for the reference genotype 'CDC Redberry' (Ramsay et al. 2014). The complexity and large genome size coupled with small research community have not allowed undertaking genome sequencing of faba bean.

NGS methods are also being employed for wholegenome re-sequencing (WGRS) and restriction site-associated DNA (RAD) sequencing of germplasm lines for exploring genetic diversity and population dynamics (Varshney et al. 2013b). Like the above-mentioned techniques, genotyping by sequencing (GBS) is another NGS-based platform that allows simultaneous discovery and mapping of several thousands of genetic markers (Davey et al. 2011). In lentil, the NGS-GBS approach has facilitated detection and mapping of genome-wide SNPs (Temel et al. 2014). Advances in sequencing technologies and collaborative efforts are expected to deliver draft genome sequences in all the pulse crops in the very recent future. It is also anticipated that re-sequencing of germplasm collections in these pulse crops will provide estimates on genome diversity and detailed population structure of germplasm collections.

\section{Trait mapping/gene(s) discovery in pulse crops}

Identification of a gene/QTL underlying the trait of interest is the most critical step while proceeding for markerassisted selection (MAS)/GAB. Among various genomic resources, molecular markers are of direct application in crop breeding, as these are heavily deployed in trait mapping studies using either family-based linkage (FBL) mapping approaches or germplasm-based association mapping (AM) (Mackay and Powell 2007). An appropriately built experimental population with considerable size lies at the core of FBL-based QTL discovery studies (Mitchell-Olds 2010). Alternatively, non-experimental population or a set of genetically diverse genotypes can be used for uncovering the genetic architecture of important traits via linkage disequilibrium (LD) analysis or AM (Mackay and Powell 2007). Trait mapping using linkage or association analysis corresponds to a forward genetics approach, in which phenotypic expression is usually known and the phenotypic variation is therefore targeted for detecting causal genetic polymorphisms. In contrast, a reverse genetics method, more precisely a locus-to-phenotype approach, relies on determination of the function of a known sequence ( $\mathrm{McCa}-$ llum et al. 2000).

Genetic populations: bi-parental and multi-parental mapping resources

The family-based populations are usually derived from two genotypes showing sufficient phenotypic diversity for few traits. Among the different types of populations available, the genetic constitution of $\mathrm{F}_{2}$ or backcross (BC) harbours considerable heterozygosity, thus limiting opportunities for replicated measurements (Collard et al. 2005). By contrast, the nearly homozygous nature of recombinant inbred (RI) populations enables multi-location and multi-season screening of the population, which eventually enhances the strength of QTL detection (Varshney et al. 2009c). In pulses, numerous experimental populations have been developed belonging to both narrow (intraspecific)- and broad (interspecific)-based crosses, facilitating construction of several population-specific genetic maps and molecular tagging/mapping of the targeted traits (Table 2; Table 3a, b).

Bi-parental mapping populations are endowed with greater power for detection of QTLs; however, the mapping resolution i.e. precision is not adequate, thus making these populations (except NILs) suitable for coarse mapping only (Cavanagh et al. 2008). The map resolution can be enhanced by (1) incorporating multiple alleles in a segregating population and (2) introducing provisions for inter-mating in the advanced generations (Korte and Farlow 2013). In view of the above considerations, a novel methodology known as multi-parent advanced generation intercross (MAGIC) has been introduced in plants (Mackay and Powell 2007). The MAGIC scheme is capable of exploiting wide genetic variation existing among the multiple founders (Cavanagh et al. 2008). Further, provisions for intermating open up new opportunities for recovery of a large number of informative recombinants, which is otherwise not feasible in case of traditional bi-parent populations.

Like RI populations, MAGIC lines represent immortal mapping resource suitable for joint linkage association analysis (Xu et al. 2012b). Recent achievements of MAGIC in Arabidopsis, wheat and rice (see Bandillo et al. 2013) have placed emphasis towards inclusion of multiple parents while generating experimental populations in pulse crops. Consequently, with support of the CGIAR Generation Challenge Programme (GCP), development of meta-population derived from eight founders (or MAGIC, with 8 parental lines) is underway in cowpea (Ribaut et al. 2012; https://sites.google.com/site/ijmackay/work/magic). Besides fine mapping of QTL(s), the stable MAGIC lines have direct or indirect applications in germplasm 
enhancement and cultivar development (Bandillo et al. 2013). Likewise, another multi-parent based approach, i.e. nested association mapping (NAM) also permits both FBL and LD analyses (Cook et al. 2012; McMullen et al. 2009; Tian et al. 2011). The availability of genome sequence of the reference genotype in almost all the major pulse crops will help greatly for using the reference genotype as common parent for developing a series of connected bi-parental RI populations that constitutes the NAM design (McMullen et al. 2009).

Genetic linkage maps and QTLs

Recent advances in marker systems starting from limited morphological markers to abundant sequence-based markers have taken genetic mapping to the next level where the mapping populations can be explored best for superior alleles. In the context of genetic mapping, pea is one of the pioneer crops in which several morphological markers were successfully mapped using classical genetics approaches. For instance, the pea mutation map was developed by mapping 169 morphological markers (Blixt 1972). Similar instances were reported in other pulse crops like lentil, where the initial genetic maps were based on morphological and isozyme markers (Zamir and Ladizinsky 1984).

Highly saturated genetic maps and precisely mapped QTLs are the essential tools for undertaking GAB. A quantum leap in the marker systems towards easy-to-use SNP markers has led to the development of highly saturated genetic maps in the major pulse crops. The core mapping populations were used to develop functional or transcript maps in these crops such as SNP-based maps developed for 'China $\times$ Cameor' and 'Orb $\times$ CDC Striker' in pea (Deulvot et al. 2010; Sindhu et al. 2013), 'CDC Robin $\times$ 964a46' (LR-18) in lentil (Fedoruk et al. 2013; Sharpe et al. 2013) and 'Icarus $\times$ Ascot' in faba bean (Kaur et al. 2014). These genetic maps provided map locations to a number of markers with considerable genome coverage, e.g. 543 loci (834.7 cM) in lentil (Sharpe et al. 2013). Further, a detailed list of population-specific genetic maps in four selected pulse crops is presented in Table 2 .

In parallel, the segregation data from diverse mapping populations are analysed to synthesize a much broader and species-specific genetic map known as 'consensus' or 'composite' map (see Bohra 2013). Moderate- to highdensity consensus maps have been reported in pea (Hamon et al. 2011, 2013; Loridon et al. 2005), cowpea (Lucas et al. 2011; Muchero et al. 2009a) and faba bean (Román et al. 2004; Satovic et al. 1996, 2013; Vaz Patto et al. 1999) offering higher mapping resolution and better genome coverage. Among pulse crops, a comprehensive consensus map was established for cowpea using 700 individuals belonging to six different RILs. The six component or population-specific genetic maps had loci ranging from 288 to 436 with several common SNPs mapped in different populations. Subsequently, with the help of bridge SNPs, all six component maps were combined into a single, high-density and robust consensus map with 645 bins encompassing 928 loci and 680 cM (Muchero et al. 2009a). This map was further refined by Lucas et al. (2011) with 1,107 SNPs arranged in 856 bins, thus increasing marker density from $0.73 \mathrm{cM}$ (Muchero et al. 2009a) to $0.61 \mathrm{cM}$ (http://harvest.ucr.edu). Similarly, notable consensus maps were developed for pea and faba bean comprising 619 loci (1,513 cM) and 729 loci (4,602 cM), respectively (Hamon et al. 2013; Satovic et al. 2013). More recently, Duarte et al. (2014) combined data from four different RILs in pea and synthesized a highly saturated consensus genetic map with 2,070 loci covering 1,255 cM. Moreover, the metaQTL analysis using consensus/composite maps enable placing of several QTLs from multiple populations onto a single genetic map, thus enhancing the QTL resolution and additionally incorporating more informative markers into the QTL-containing regions (Hamon et al. 2013).

The linkage map-based QTLs controlling several agriculturally important traits have been identified in almost all the major pulse crops (Table 3 ). In the absence of a genetic linkage map, bulked segregants analysis (BSA) is usually performed to find DNA markers tightly associated with the concerned trait, mostly resistance to biotic stresses (Table 3). BSA using NILs is a powerful mapping strategy widely used for understanding marker-trait relationships (Gepts et al. 2008). The noteworthy examples of BSAbased molecular tagging in pulses include various types of markers such as random amplification of polymorphic DNA (RAPD)/amplified fragment length polymorphism (AFLP)/sequence-characterized amplified region (SCAR)/ cleaved amplified polymorphic sequence (CAPS) markers, which were employed for screening Ascochyta blight resistance in lentil (Chowdhury et al. 2001), Striga resistance in cowpea (Boukar et al. 2004; Ouedraogo et al. 2001), powdery mildew in pea (Pereira et al. 2010) and growth habit in faba bean (Avila et al. 2006, 2007) (Table 3a). The GAB approaches have been limited till now due to unavailability of such relevant DNA markers; however, the above identified markers linked to agronomically important traits along with additional markers for other important traits in coming days from ongoing mapping projects will help to commence GAB in these pulse crops.

Harnessing allelic variation through association genetics

Given segregation of only two alleles, the FBL mapping is the most appropriate method for capturing rare alleles; however, it lacks precision in locating QTLs within the genome (Cavanagh et al. 2008). In contrast to FBL, AM 


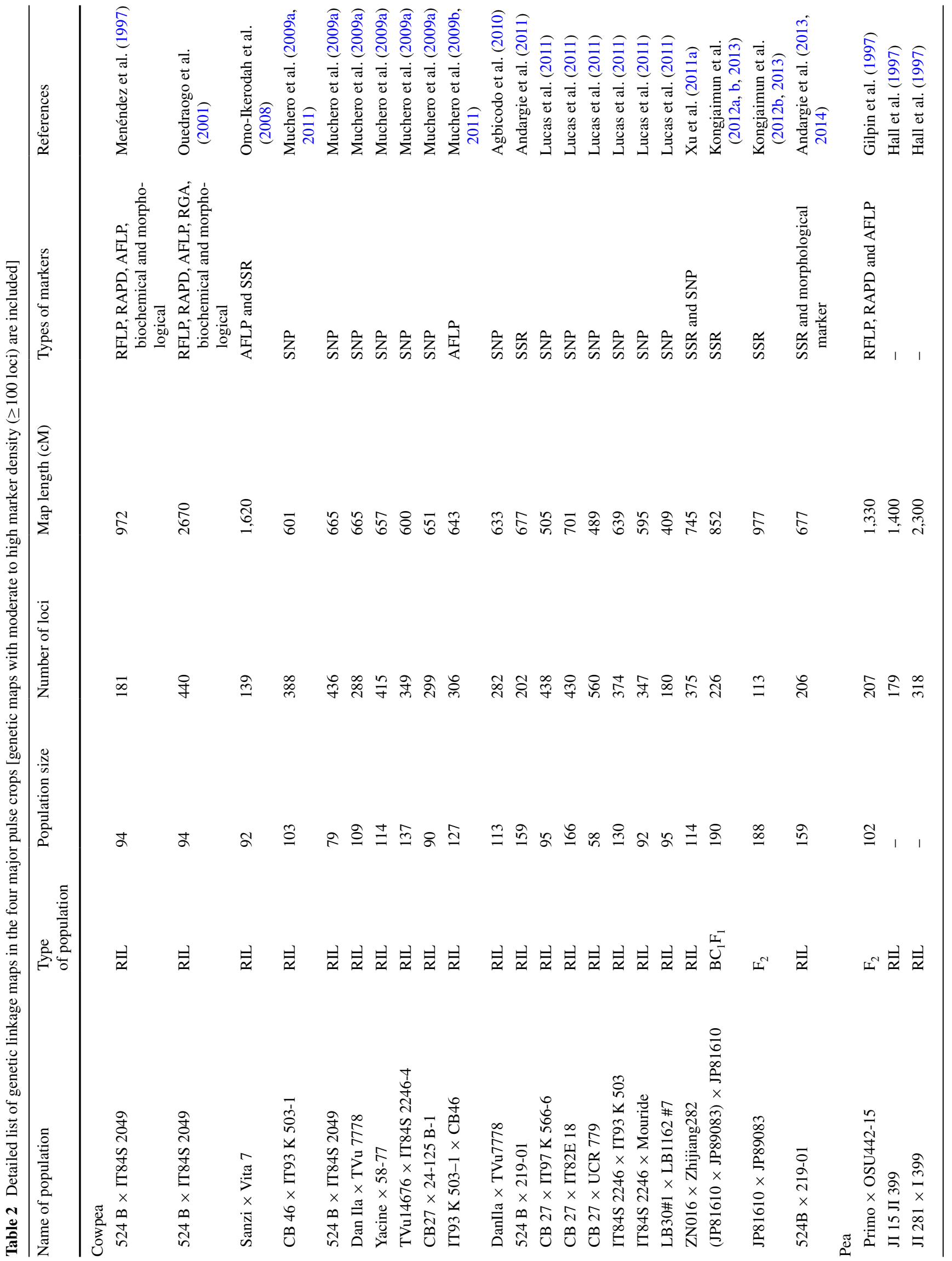




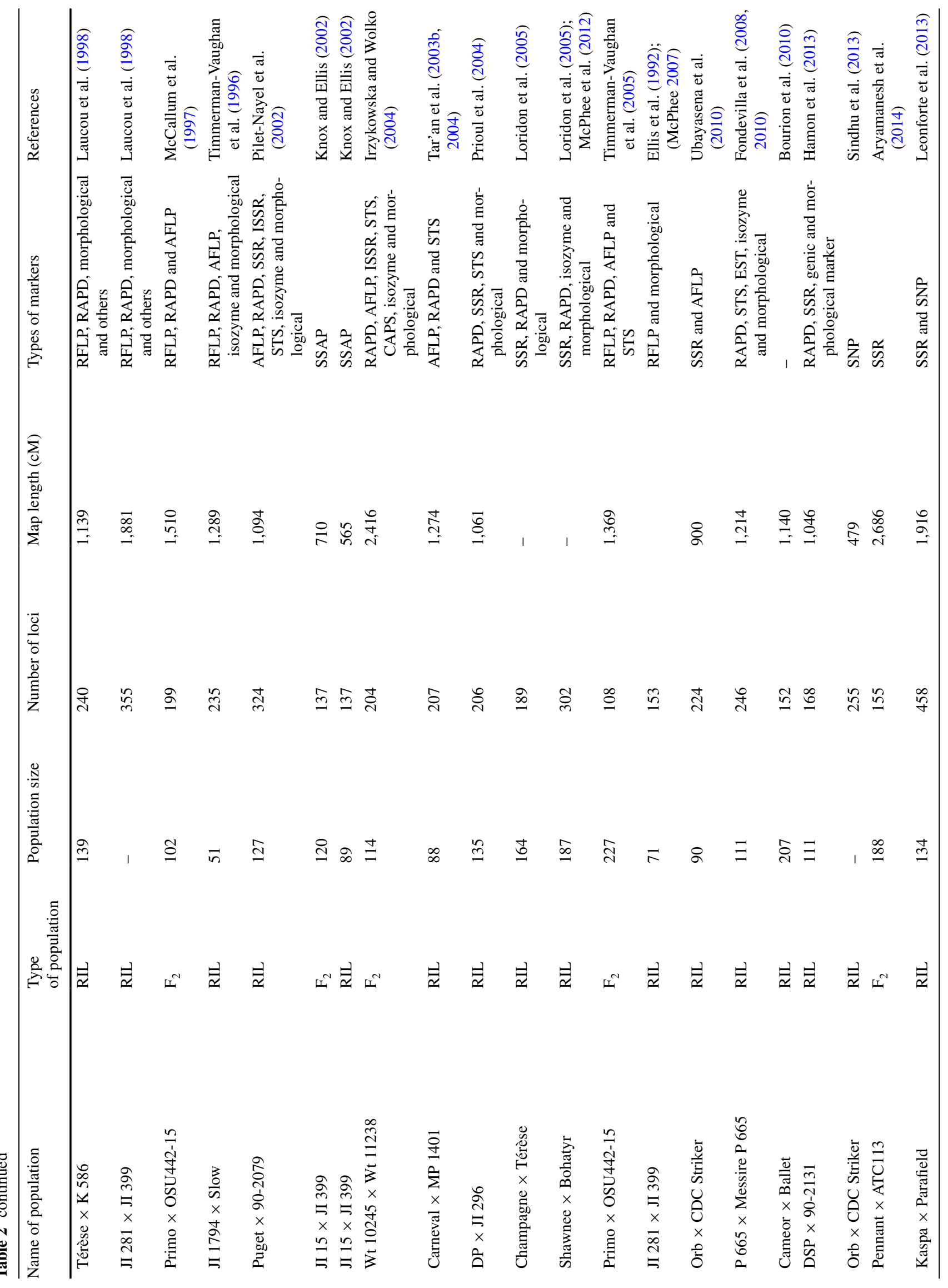




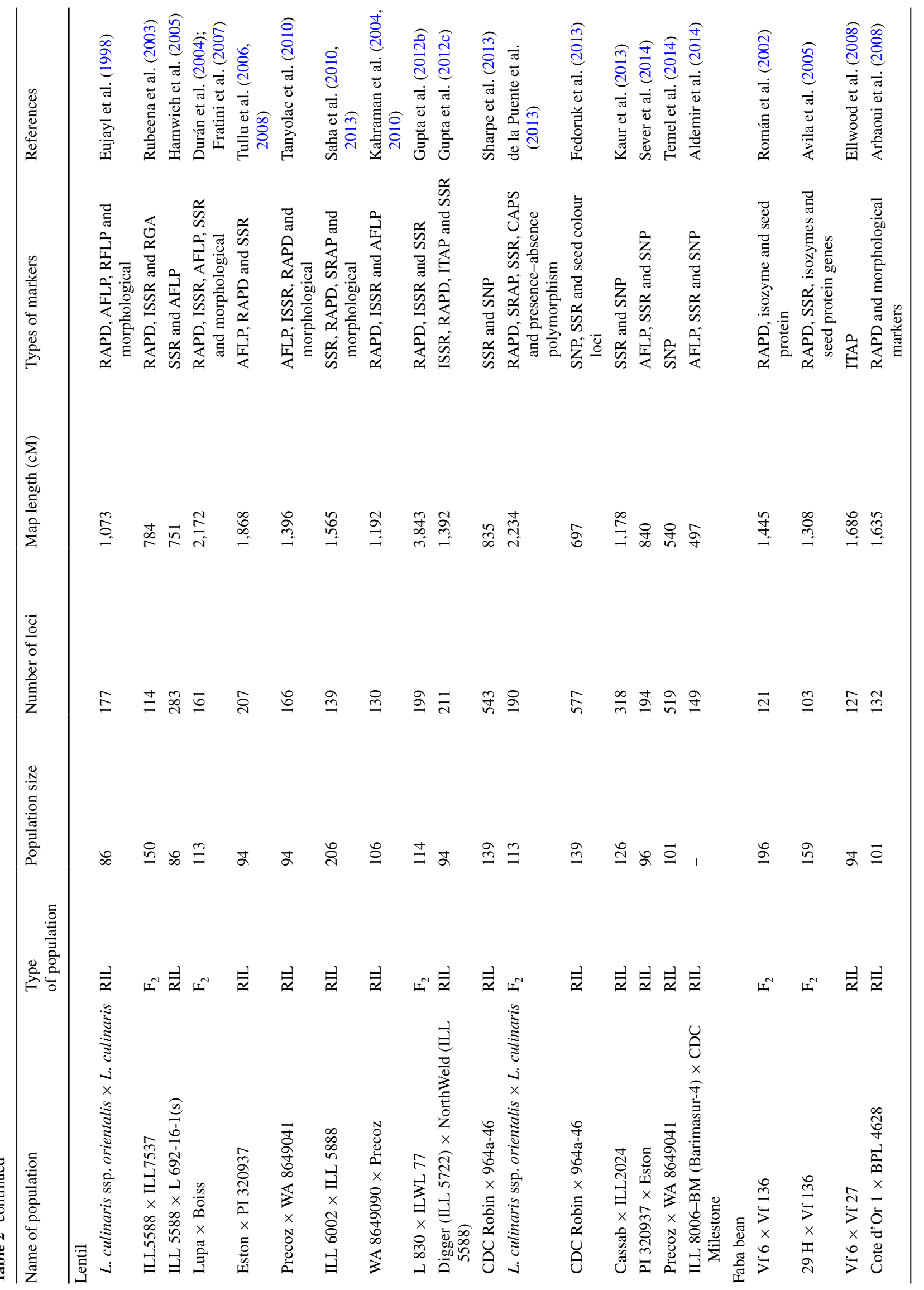




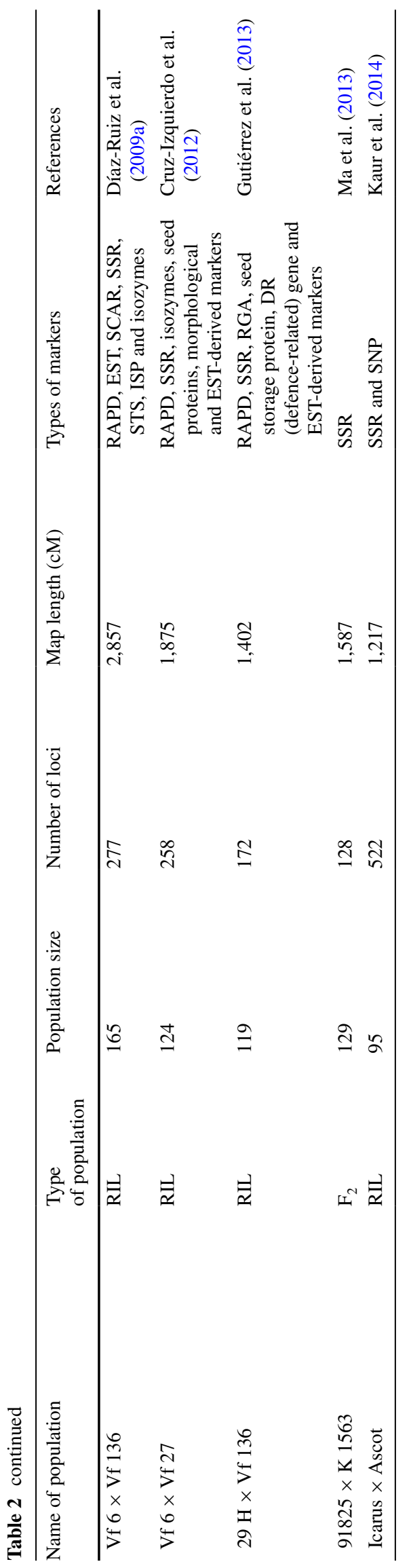

tests non-random association of alleles or LD in a set of diverse and non-related individuals with no extra efforts given to the generation of a large experimental population (Mackay and Powell 2007). In AM, establishing a markertrait association largely depends on the rate of LD decay. Although not uniform across the whole genome, LD decays at a much higher rate in outbreeding crops compared to self-pollinated species (Yu and Buckler 2006). However, successful instances of LD analyses in various self-pollinated species like barley (Cockram et al. 2010), and subsequently in several species like rice and wheat (see Galeano et al. 2012), offer new prospects for AM-based discovery of important QTL-containing regions in pulses as well.

With increasing availability of large-scale genetic markers in most of the pulse crops, AM would likely be the method of choice for high-resolution QTL discovery. For instance, the AM method was applied to diverse collections from 'USDA Pea Core' to examine the associations of various candidate genes with yield/yield-relevant traits and, consequently, the role of some pea homologues of APETALA2 (AP2) and GA 3-oxidase (GA3ox) with regard to yield was revealed (Murray et al. 2009). Kwon et al. (2012) also analysed the marker (SSR, RAPD and SCAR) and phenotyping data in 285 USDA pea core accessions using models such as generalized linear model (GLM) and mixed linear model (MLM) and significant marker-trait linkages were obtained for mineral nutrient concentrations, disease/pest resistance and other important morphological traits.

By estimating genome-wide LD decay in asparagus bean, $\mathrm{Xu}$ et al. (2012a) proposed that LD extends up to a long physical distance $(\sim 2 \mathrm{cM}$ or $1.86 \mathrm{Mb})$ in asparagus bean. Besides advocating the existing hypothesis about unguiculata-sesquipedalis divergence, this investigation provided novel insights such as the role of three specific chromosomes during cowpea domestication. These three LGs (5, 7 and 11) showed markedly different patterns of LD decay between the two cultivar groups, viz. unguiculata and sesquipedalis. From the trait mapping perspective, this study offered a concrete framework for initiating genome-wide association (GWA)-based dissection of complex traits in cowpea. More recently, Muchero et al. (2013) performed whole-genome scan in a panel of 383 diverse cowpea accessions using 865 SNPs. The MLM approach identified several QTL regions associated with delayed senescence, biomass and yield/yield components. Moreover, the report also provided evidences about the presence of pleiotropic-effect QTLs for stay-green trait in cowpea. Furthermore, QTLs for delayed senescence, drought tolerance and yield were validated in another RIL population (IT93 K-503-1 × CB46). In a similar way, the GWA study involving 171 cowpea accessions confirmed the existence of seed weight-QTLs (Css 1-10), which 
Table 3 Trait mapping in selected pulse crops

\begin{tabular}{|c|c|c|c|c|c|c|c|}
\hline \multicolumn{2}{|l|}{ Trait } & \multicolumn{2}{|l|}{ Name of the population } & \multicolumn{2}{|c|}{ Associated marker(s) } & \multicolumn{2}{|c|}{ Reference } \\
\hline \multicolumn{8}{|l|}{ a) BSA-based molecular tagging } \\
\hline \multicolumn{8}{|l|}{ Cowpea } \\
\hline \multicolumn{2}{|l|}{ Cowpea golden mosaic virus } & \multicolumn{2}{|c|}{ IT97 K-499-35 × Canapu T16 } & \multicolumn{2}{|l|}{ AFLP } & \multicolumn{2}{|c|}{ Rodrigues et al. (2012) } \\
\hline \multirow{4}{*}{\multicolumn{2}{|c|}{ Striga resistance }} & \multicolumn{2}{|l|}{ Tvx $3236 \times$ IT82D-849 } & \multicolumn{2}{|l|}{ AFLP } & \multicolumn{2}{|c|}{ Ouedraogo et al. (2001) } \\
\hline & & \multicolumn{2}{|c|}{ Tvu $14676 \times$ IT84S-2246-4 } & \multicolumn{2}{|l|}{ AFLP } & \multicolumn{2}{|c|}{ Ouedraogo et al. (2001) } \\
\hline & & \multicolumn{2}{|l|}{ IT84S-2246 × Tvu14676 } & \multicolumn{2}{|l|}{ SCAR } & \multicolumn{2}{|c|}{ Ouedraogo et al. (2012) } \\
\hline & & \multicolumn{2}{|c|}{ IT93 K-693-2 × IAR1696 } & \multicolumn{2}{|c|}{ AFLP/SCAR } & Bouka & ar et al. (2004) \\
\hline Pea & & & & & & & \\
\hline Development funiculus (def) & & $\mathrm{DGV} \times \mathrm{PF}$ & & AFLP/S & & von $\mathrm{St}$ & tackelberg et al. (2003) \\
\hline Determinate growth (det) & & JI2121 × Térèse & & RAPD & & Rame & au et al. (1998) \\
\hline Fascinated stem (fa) & & JI814 × Térèse & & RAPD & & Rame & au et al. (1998) \\
\hline Increased branching (rms) & & K524 × Térèse & & RAPD & & Rame & au et al. (1998) \\
\hline & & WL6042 × Térèse & & RAPD & & Rame & au et al. (1998) \\
\hline & & M3T-946 × Torsdag & & RAPD & & Rame & au et al. (1998) \\
\hline Nodulation loci & & $\mathrm{P} 56 \times \mathrm{JI} 15 \mathrm{P} 2 \times \mathrm{JI} 281$ & $\mathrm{P} 54 \times \mathrm{JI} 281$ & RFLP & & Schne & ider et al. (2002) \\
\hline Pea seed-borne mosaic virus ( $\mathrm{H}$ & PSbMV) & $88 \mathrm{~V} 1.11 \times 425$ & & RFLP & & Timm & erman et al. (1993) \\
\hline Photoperiod insensitivity (dne) & & K218 × Térèse & & RAPD & & Rame & au et al. (1998) \\
\hline Photoperiod insensitivity (sn) & & HL59 $\times$ Térèse & & RAPD & & Rame & au et al. (1998) \\
\hline Powdery mildew & & Radley $\times$ Highlight & & RAPD/S & CAR & Tiwar & i et al. (1998) \\
\hline & & Majoret $\times 955180$ & & SSR & & Ek et & al. (2005) \\
\hline & & Solara $\times$ Frilene-derivec & mutant & SCAR & & Pereir & a et al. (2010) \\
\hline & & Sparkle $\times$ Mexique & & RAPD/S & CAR & Tongu & ç and Weeden (2010) \\
\hline Fusarium wilt (race 1) resistan & & Green Arrow × PI 1794 & & TRAP & & Kwon & et al. (2013) \\
\hline Lentil & & & & & & & \\
\hline Ascochyta blight resistance & & ILL5588 × ILL6002 & & RAPD & & Ford e & et al. (1999) \\
\hline & & Eston $\times$ Indian head & & RAPD/S & CAR & Chow & dhury et al. (2001) \\
\hline Fusarium vascular wilt & & ILL5588 × L692-16-1 & & RAPD & & Eujay & l et al. (1998) \\
\hline Radiation frost tolerance $(F r t)$ & & ILL5588 × L692-16-1 & & RAPD & & Eujay & l et al. (1999) \\
\hline Anthracnose resistance (LCt-2) & & Eston $\times$ PI 320937 & & AFLP/R & APD & Tullu & et al. (2003) \\
\hline Faba bean & & & & & & & \\
\hline Rust resistance & & $2 \mathrm{~N} 52 \times \mathrm{VF}-176$ & & RAPD & & Avila & et al. (2003) \\
\hline Determinate growth habit & & Verde Bonita $\times 2 \mathrm{~N} 52$ & & CAPS & & Avila & et al. (2006) \\
\hline Reduced vicine and convicine & content & Vf $6 \times 1268$ & & CAPS & & Gutiér & rrez et al. (2006) \\
\hline Absence of tannin & & Vf $6 \times \mathrm{zt}-1$ line & & SCAR & & Gutiér & rez et al. (2007) \\
\hline & & Vf $6 \times \mathrm{zt}-2$ line & & SCAR & & Gutiér & rez et al. (2008) \\
\hline Trait & Name c & f population & $\begin{array}{l}\text { Marker asso } \\
\text { QTL(s) }\end{array}$ & ated with & $\begin{array}{l}\text { PV explaine } \\
\text { QTLs }(\%)^{*}\end{array}$ & by the & Reference \\
\hline b) Linkage map/QTL-based mol & lecular $\mathrm{m}$ & apping & & & & & \\
\hline Cowpea & & & & & & & \\
\hline $\begin{array}{l}\text { Cowpea bacterial blight } \\
\text { (CoBB) resistance }\end{array}$ & DanIla & $\times \mathrm{TVu} 7778$ & SNP & & 22 & & Agbicodo et al. (2010) \\
\hline Drought-induced senescence & IT93K & $03-1 \times \mathrm{CB} 46$ & AFLP & & 24 & & Muchero et al. (2009b) \\
\hline Flower bud thrips resistance & Sanzi $>$ & Vita 7 & AFLP & & 77 & & Omo-Ikerodah et al. (2008) \\
\hline Foliar thrips & $\begin{array}{r}\mathrm{CB} 46> \\
\mathrm{CB} 27\end{array}$ & $\begin{array}{l}\text { IT93 K-503-1 and } \\
\times \text { IT } 82 E-18\end{array}$ & SNP & & 32 & & Lucas et al. (2012) \\
\hline Hastate leaf shape & Sanzi $\times$ & Vita 7 & SNP & & 74 & & Pottorff et al. (2012a) \\
\hline Pod fibre layer thickness & $524 \mathrm{~B} \times$ & 219-01 & SSR & & 17 & & Andargie et al. (2011) \\
\hline Pod length & (JP816 & $0 \times \mathrm{JP} 89083) \times \mathrm{JP} 81610$ & SSR & & 31 & & Kongjaimun et al. (2012a) \\
\hline Domestication-related traits & (JP816 & $0 \times \mathrm{JP} 89083) \times \mathrm{JP} 81610$ & SSR & & 53 & & Kongjaimun et al. (2012b) \\
\hline
\end{tabular}


Table 3 continued

\begin{tabular}{|c|c|c|c|c|}
\hline Trait & Name of population & $\begin{array}{l}\text { Marker associated with } \\
\text { QTL(s) }\end{array}$ & $\begin{array}{l}\text { PV explained by the } \\
\text { QTLs (\%) }\end{array}$ & Reference \\
\hline \multirow[t]{2}{*}{ Seed weight } & IT2246-4 × TVNI 963 & RFLP & 53 & Fatokun et al. (1992) \\
\hline & $524 \mathrm{~B} \times 219-01$ & SSR & 19 & Andargie et al. (2011) \\
\hline Charcoal rot resistance & IT93 K-503-1 × CB46 & SNP and AFLP & 40 & Muchero et al. (2011) \\
\hline Flower and seed coat colour & ZN016 $\times$ Zhijiang 28-2 & SNP & - & Xu et al. (2011b) \\
\hline Time of flower opening & $524 \mathrm{~B} \times 219-01$ & SSR & 30 & Andargie et al. (2013) \\
\hline \multirow[t]{2}{*}{ Days to flower } & $524 \mathrm{~B} \times 219-01$ & SSR & 19 & Andargie et al. (2013) \\
\hline & $\mathrm{ZN} 016 \times \mathrm{ZJ} 282$ & SNP & 32 & Xu et al. (2013) \\
\hline Nodes to first flower & $\mathrm{ZN} 016 \times \mathrm{ZJ} 282$ & SNP & 22 & Xu et al. (2013) \\
\hline Pod number per plant & $\mathrm{ZN} 016 \times \mathrm{ZJ} 282$ & SSR & 20 & Xu et al. (2013) \\
\hline Leaf senescence & $\mathrm{ZN} 016 \times \mathrm{ZJ} 282$ & SNP & 29 & Xu et al. (2013) \\
\hline Floral scent compounds & $524 \mathrm{~B} \times 219-01$ & SSR & 60 & Andargie et al. (2014) \\
\hline Heat tolerance & $\mathrm{CB} 27 \times \mathrm{IT} 82 \mathrm{E}-18$ & SNP & 18 & Lucas et al. (2013a) \\
\hline Seed size & Eight different populations & SNP & 47 & Lucas et al. (2013b) \\
\hline \multicolumn{2}{|c|}{$\begin{array}{l}\text { Fusarium wilt resistance (Fot CB27 × 24-125B-1 } \\
\text { race } 3 \text { ) }\end{array}$} & SNP & 28 & Pottorff et al. (2012b) \\
\hline \multicolumn{2}{|c|}{$\begin{array}{l}\text { Fusarium wilt resistance (Fot IT93 K-503-19 CB46 } \\
\text { race 4) }\end{array}$} & SNP & 47 & Pottorff et al. (2014) \\
\hline \multirow{4}{*}{ Pod tenderness } & $\mathrm{CB} 27 \times 24-125 \mathrm{~B}-1$ & SNP & 40 & Pottorff et al. (2014) \\
\hline & CB27 $\times$ IT82E -18 & SNP & 27 & Pottorff et al. (2014) \\
\hline & $(\mathrm{JP} 81610 \times \mathrm{JP} 89083) \times \mathrm{JP} 81610$ & SSR & 50 & Kongjaimun et al. (2013) \\
\hline & $\mathrm{JP} 81610 \times \mathrm{JP} 89083$ & SSR & 43 & Kongjaimun et al. (2013) \\
\hline \multicolumn{5}{|l|}{ Pea } \\
\hline \multirow[t]{4}{*}{ Aphanomyces root rot } & Puget $\times 90-2079$ & AFLP & 47 & Pilet-Nayel et al. (2002) \\
\hline & Baccara $\times$ PI 180693 & - & 49 & Hamon et al. (2011) \\
\hline & Baccara $\times 552$ & - & 21 & Hamon et al. (2011) \\
\hline & DSP $\times 90-2131$ & - & 60 & Hamon et al. (2013) \\
\hline \multirow[t]{3}{*}{ Ascochyta blight resistance } & A88 $\times$ Rovar & - & 35 & $\begin{array}{l}\text { Timmerman-Vaughan et al. } \\
\text { (2002) }\end{array}$ \\
\hline & $\mathrm{DP} \times \mathrm{JI} 296$ & - & 74 & Prioul et al. (2004) \\
\hline & P665 × Messire. P665 & - & 75 & Fondevilla et al. (2008) \\
\hline Days to maturity & Carneval $\times$ MP1401 & - & 34 & Tar' an et al. (2004) \\
\hline Frost resistance & Champagne $\times$ Terese & - & 45 & Dumont et al. (2009) \\
\hline Grain yield & Carneval $\times$ MP1401 & - & 38 & Tar'an et al. (2004) \\
\hline Lodging resistance & Carneval $\times$ MP1401 & AFLP/SCAR & 58 & Tar'an et al. $(2003 b, 2004)$ \\
\hline $\begin{array}{l}\text { Mycosphaerella blight resist- } \\
\text { ance }\end{array}$ & Carneval × MP1401 & - & 36 & Tar'an et al. $(2003 b, 2004)$ \\
\hline \multirow[t]{2}{*}{ Plant height } & Erygel $\times 661$ & RFLP & 19 & Dirlewanger et al. (1994) \\
\hline & Carneval $\times$ MP1401 & - & 65 & Tar'an et al. (2003b, 2004) \\
\hline Plant maturity & A26 × Rovar & - & 27 & $\begin{array}{l}\text { Timmerman-Vaughan et al. } \\
\text { (2004) }\end{array}$ \\
\hline Seed protein concentration & Carneval $\times$ MP1401 & - & 45 & Tar'an et al. (2004) \\
\hline Seed weight & Primo $\times$ OSU442-15 & RAPD & 62 & $\begin{array}{l}\text { Timmerman-Vaughan et al. } \\
\text { (1996) }\end{array}$ \\
\hline $\begin{array}{l}\text { Yield component and devel- } \\
\text { opmental traits }\end{array}$ & Primo $\times$ OSU442-15 & - & 62 & $\begin{array}{l}\text { Timmerman-Vaughan et al. } \\
\text { (2005) }\end{array}$ \\
\hline $\begin{array}{l}\text { Yield-related traits and seed } \\
\text { protein content }\end{array}$ & Wt10245 × Wt11238 & - & 56 & $\begin{array}{l}\text { Irzykowska and Wolko } \\
\text { (2004) }\end{array}$ \\
\hline Pea weevil & Pennant $\times$ ATC113 & SSR & 43 & Aryamanesh et al. (2014) \\
\hline $\begin{array}{l}\text { Fusarium wilt (race 2) resist- } \\
\text { ance }\end{array}$ & Shawnee $\times$ Bohatyr & SSR & 80 & McPhee et al. (2012) \\
\hline
\end{tabular}


Table 3 continued

\begin{tabular}{|c|c|c|c|c|}
\hline Trait & Name of population & $\begin{array}{l}\text { Marker associated with } \\
\text { QTL(s) }\end{array}$ & $\begin{array}{l}\text { PV explained by the } \\
\text { QTLs }(\%)^{*}\end{array}$ & Reference \\
\hline Salt tolerance & Kaspa $\times$ Parafield & SNP & 19 & Leonforte et al. (2013) \\
\hline \multicolumn{5}{|l|}{ Lentil } \\
\hline \multirow[t]{4}{*}{ Ascochyta blight resistance } & ILL $7537 \times$ ILL 6002 & AFLP & 47 & Rubeena et al. (2003) \\
\hline & Eston $\times$ PI320937 & AFLP and RAPD & 50 & Tullu et al. (2006) \\
\hline & $\begin{array}{l}\text { Digger (ILL5722) } \times \text { NorthWeld } \\
\text { (ILL5588) }\end{array}$ & ITAP, SSR and ISSR & 61 & Gupta et al. (2012b) \\
\hline & $\begin{array}{l}\text { ILL5588 } \times \text { ILL7537 and } \\
\text { ILL7537 } \times \text { ILL6002 }\end{array}$ & - & 50 & Rubeena et al. (2006) \\
\hline Earliness & Eston $\times$ PI320937 & RAPD and AFLP & 46 & Tullu et al. (2008) \\
\hline \multirow[t]{2}{*}{ Plant height } & Eston $\times$ PI320937 & AFLP and SSR & 40 & Tullu et al. (2008) \\
\hline & Lupa $\times$ Boiss & - & 38 & Fratini et al. (2007) \\
\hline \multicolumn{2}{|c|}{ Stemphylium blight resistance ILL-6002 $\times$ ILL-5888 } & SRAP and RAPD & 46 & Saha et al. (2010) \\
\hline Winter hardiness & WA8649090 $\times$ Precoz & ISSR & 43 & Kahraman et al. (2010) \\
\hline Seed thickness & CDC Robin × 964a-46 & $\begin{array}{l}\text { Morphological marker } \\
\text { (cotyledon colour locus } \\
(\mathrm{Yc}))\end{array}$ & 38 & Fedoruk et al. (2013) \\
\hline Seed plumpness & CDC Robin $\times 964 a-46$ & $\begin{array}{l}\text { Cotyledon colour locus } \\
\text { (Yc) }\end{array}$ & 40 & Fedoruk et al. (2013) \\
\hline \multirow[t]{2}{*}{ Days to $50 \%$ flowering } & CDC Robin $\times 964 a-46$ & $\begin{array}{l}\text { Cotyledon colour locus } \\
\text { (Yc) }\end{array}$ & 35 & Fedoruk et al. (2013) \\
\hline & ILL $6002 \times$ ILL 5888 & SSR/RAPD/SRAP & 20 & Saha et al. (2013) \\
\hline \multirow[t]{2}{*}{ Seed diameter } & Lupa $\times$ Boiss & - & 37 & Fratini et al. (2007) \\
\hline & ILL $6002 \times$ ILL 5888 & SSR/RAPD/SRAP & 32 & Saha et al. (2013) \\
\hline \multirow[t]{2}{*}{ Seed weight } & Lupa $\times$ Boiss & - & 18 & Fratini et al. (2007) \\
\hline & ILL $6002 \times$ ILL 5888 & SSR/RAPD/SRAP & 18 & Saha et al. (2013) \\
\hline Boron tolerance & Cassab $\times$ ILL2024 & SNP & 71 & Kaur et al. (2013) \\
\hline \multicolumn{5}{|l|}{ Faba bean } \\
\hline \multirow[t]{4}{*}{ Ascochyta blight resistance } & $29 \mathrm{H} \times \mathrm{Vf} 136$ & RAPD & 45 & Avila et al. (2004) \\
\hline & Vf $6 \times$ Vf 136 & RAPD & 25 & Román et al. (2003) \\
\hline & Vf $6 \times$ Vf 136 & RAPD & 24 & Díaz-Ruiz et al. (2009a) \\
\hline & Icarus $\times$ Ascot & SNP & 20 & Kaur et al. (2014) \\
\hline \multirow[t]{3}{*}{ Broomrape resistance } & Vf $6 \times$ Vf 136 & RAPD & 35 & Román et al. (2002) \\
\hline & Vf $6 \times$ Vf 136 & RAPD & 43 & Díaz-Ruiz et al. (2009b) \\
\hline & $29 \mathrm{H} \times \mathrm{Vf} 136$ & RAPD & 33 & Gutiérrez et al. (2013) \\
\hline Floral characters & $29 \mathrm{H} \times \mathrm{Vf} 136$ & RAPD & 20 & Avila et al. (2005) \\
\hline Days to flowering & Vf $6 \times$ Vf 27 & SSR & 28 & $\begin{array}{l}\text { Cruz-Izquierdo et al. } \\
\text { (2012) }\end{array}$ \\
\hline Flowering length & Vf $6 \times$ Vf 27 & EST-derived marker & 31 & $\begin{array}{l}\text { Cruz-Izquierdo et al. } \\
\text { (2012) }\end{array}$ \\
\hline Pod length & Vf $6 \times$ Vf 27 & SSR & 25 & $\begin{array}{l}\text { Cruz-Izquierdo et al. } \\
\text { (2012) }\end{array}$ \\
\hline Number of ovules per pod & Vf $6 \times$ Vf 27 & EST-derived marker & 27 & $\begin{array}{l}\text { Cruz-Izquierdo et al. } \\
\text { (2012) }\end{array}$ \\
\hline Number of seeds per pod & Vf $6 \times$ Vf 27 & RAPD & 26 & $\begin{array}{l}\text { Cruz-Izquierdo et al. } \\
\text { (2012) }\end{array}$ \\
\hline Seed weight & - & RAPD & 30 & Vaz Patto et al. (1999) \\
\hline Yield characters & $29 \mathrm{H} \times \mathrm{Vf} 136$ & RAPD & 58 & Avila et al. (2005) \\
\hline Frost tolerance & Coted'Or $1 \times$ BPL 4628 & RAPD & 40 & Arbaoui et al. (2008) \\
\hline Fatty acid content & Coted'Or $1 \times$ BPL 4628 & RAPD & 63 & Arbaoui et al. (2008) \\
\hline
\end{tabular}

* QTLs with the highest phenotypic variation (PV) are shown and only major effect QTLs with PV $\geq 10 \%$ are considered 
were initially detected in eight different RI populations by family-based QTL analysis. Further, most of the underlying QTLs exhibited syntenic relationship with genomic regions controlling seed weight in soybean. Notably, one of the candidate QTLs (Css-3) colocalized with another QTL known to impart resistance to foliar thrips (Thr-1) in cowpea, whereas two other QTLs (Css-4 and Css-9) overlapped with loci governing charcoal rot resistance (Mac-6 and Mac-8) (Lucas et al. 2013b). The AM approach was also used in lentil for detection of significant QTLs associated with various seed-relevant traits. A set of 140 accessions comprising various breeding lines, cultivars and landraces was genotyped with $~ 900$ GG-based SNPs and subsequently, QTLs were recovered for seed diameter, seed thickness and seed plumpness (Fedoruk 2013).

The confounding effects of population structure or genetic relatedness, however, remain the biggest impediment to AM that often lead to the generation of various spurious associations or false positives (Korte and Farlow 2013; Mitchell-Olds 2010; Varshney et al. 2012). This limitation may be overcome through employing GWAS in MAGIC or NAM populations, which are intrinsically devoid of any complex structure (Bandillo et al. 2013; Cook et al. 2012; McMullen et al. 2009; Tian et al. 2011). In this way, multi-parent genetic populations bridge the gaps between FBL and LD-based approaches and hold great potential for high-resolution trait mapping.

Reverse genetics approaches for gene discovery

Reverse genetics comprises an array of approaches like transgenic-based as well as non-transgenic systems like virus-induced gene silencing (VIGS) and targeting-induced local lesion in genomes (TILLING). To establish a transgenic system the prerequisites are: (1) an efficient and reliable genetic transformation procedure, (2) a reproducible, economically viable and easy-to-use regeneration protocol and (3) an appropriate selectable marker with corresponding selective agent to recover transformants (Popelka et al. 2004; Svabova and Griga 2008). To introduce foreign DNA into plant cells, two techniques, viz. Agrobacterium-mediated and direct DNA transfer including electroporation, mircoprojectile bombardment and polyethylene glycol (PEG), have been used in these pulse crops (Eapen 2008; Popelka et al. 2004; Somers et al. 2003). Of all the techniques used for DNA delivery, Agrobacterium tumefaciensmediated transfer has been widely accepted as the standard method in legumes (Atif et al. 2013; Eapen 2008; Somers et al. 2003). Conversely, alternative methods involving direct DNA transfer are known to generate relatively elevated number of chimeras (Chandra and Pental 2003; Popelka et al. 2004). Nevertheless, direct DNA transfer represents the sole method for introducing a foreign gene into organellar genomes (Atif et al. 2013).

In general, the frequency of transformation in pulse crops is considerably low as compared to cereals (Atif et al. 2013; Chandra and Pental 2003; Eapen 2008). For example, some recent genetic transformation experiments have reported frequencies of 3.09-3.6\% in cowpea (Bakshi et al. 2011, 2012), 0.1-1.0 \% in pea (Svabova and Griga 2008), $0.9 \%$ in lentil (Chopra et al. 2011) and $0.15-2 \%$ in faba bean (Hanafy et al. 2005). Given the context, Svabova and Griga (2008) considered co-cultivation as a decisive step towards enhancing the transformation efficiency and evaluated the effects of application of various chemicals such as acetosyringone, L-cysteine, dithiothreitol, glutathione, cellulase and pectinase while performing co-cultivation in pea. Previously, Olhoft and Somers (2001) reported a fivefold increase in stable DNA integration by applying L-cysteine to the solid co-cultivation medium in soybean. Besides use of chemical additives, sonication and vacuum infiltrationassisted methods have also been reported to improve the efficiency of genetic transformation in these crops (Bakshi et al. 2011; Chopra et al. 2011).

Furthermore, concerning the mode of regeneration in pulse crops, direct organogenesis (without callus formation) has been preferred over somatic embryogenesis (Atif et al. 2013; Chandra and Pental 2003). However, recalcitrance and genotype-specific response of various pulse crops to these regeneration protocols are other major issues challenging their routine use in transgenic development. To overcome the issue of recalcitrance to regeneration in vitro, Somers et al. (2003) suggested exploring the possibilities of non-tissue culture-based transformation, which avoids labour-intensive culture practices and eventually eliminates other related problems including somaclonal variations (Griga et al. 1995) and differential response of genotypes to regenerate (Tague and Mantis 2006). Recently, Weeks et al. (2008) developed a genotype-independent and marker-free in planta transformation system for alfalfa (Medicago sativa) with enhanced transformation efficiency ( $7 \%$ ). Though constant refinements are being made in the transformation systems and regeneration protocols, stable transmission of a foreign gene to subsequent progenies and its predictable expression still remains challenging (Gelvin 2003; Popelka et al. 2004). Nevertheless, the transgenic-based RNA interference (RNAi) technologies have greatly helped in understanding the molecular mechanisms of nitrogen fixation in legumes. For instance, the role of Rba 2 gene in Phaseolus-Rhizobium symbiotic relationship was elucidated using RNAi technology with no induction observed for early nodulation genes (Antonio Blanco et al. 2009). In addition to exploring symbiotic nitrogen fixation, RNAi was also used to examine the mechanism of 
resistance against various biotic constraints in pulses (Bonfim et al. 2007).

The non-transgenic approaches are particularly suitable for legumes, which are not amenable to routine transformation/regeneration protocols (Tadege et al. 2009). One of such powerful and HTP techniques is TILLING, which involves chemical mutagenesis, and a sensitive mutationdetecting instrument, therefore making it amenable to automation. The basic steps followed in TILLING are: (1) generation of a TILLING population, (2) isolation and pooling of DNAs, (3) PCR amplification with genespecific labelled primers, (4) denaturation and re-annealing followed by hetero-duplex formation, (5) cleavage at mismatch using enzymes like CELI endonuclease and (6) detection of cleaved products using instruments such as LI-COR (Gilchrist and Haughn 2005; McCallum et al. 2000; Tadege et al. 2009). In pea, a global TILLING platform has been developed with two EMS-induced mutant populations from two genotypes: 'Cameor' (4,704 M2 lines) and 'Terese' (3,072 M2 lines). The 'Cameor' population, also referred to as 'reference TILLING population', successfully allowed molecular screening of 54 genes (http://www-urgv.versailles.inra.fr/tilling/pea.htm; Dalmais et al. 2008) with the notable mutation detection in the pea methyl transferase 1 gene (PsMet1). Further, the efficacy of Arabidopsis thaliana mismatch-specific endonucleases (ENDO1) to detect mutation in gibberellin 3 beta-hydrolase gene of $P$. sativum was successfully demonstrated in the 'Terese' population (Triques et al. 2007). Moreover, an in silico database 'UTILLdb' has been set up to enable access to the phenotypic expression and sequence information on mutants (Dalmais et al. 2008). TILLING has also contributed to understanding the function of pea subtilase (SBT1.1) and tendril-less $(t l)$ genes in controlling seed size and tendril formation, respectively (D'Erfurth et al. 2012; Hofer et al. 2009).

Apart from RNAi and TILLING, VIGS is another reverse genetics technique for discovery and characterization of the causative gene(s). Grønlund et al. (2010) successfully applied VIGS technique in pea to suppress genes that are involved in nitrogen-fixing Rhizobium as well as in developmental processes. Similarly, the role of CHLI and CHLD genes in tetrapyrrole biosynthesis and chloroplast development was examined in pea using the VIGS approach (Luo et al. 2013). Despite some notable achievements of reverse genetics approaches, these methods are not so popular as these are time consuming, very costly and can only be exercised in selected institutions/organizations. Nevertheless, further advancements in technology may provide better implementation of such research experimentations with generation of substantially useful information for further improvement of pulse crops.

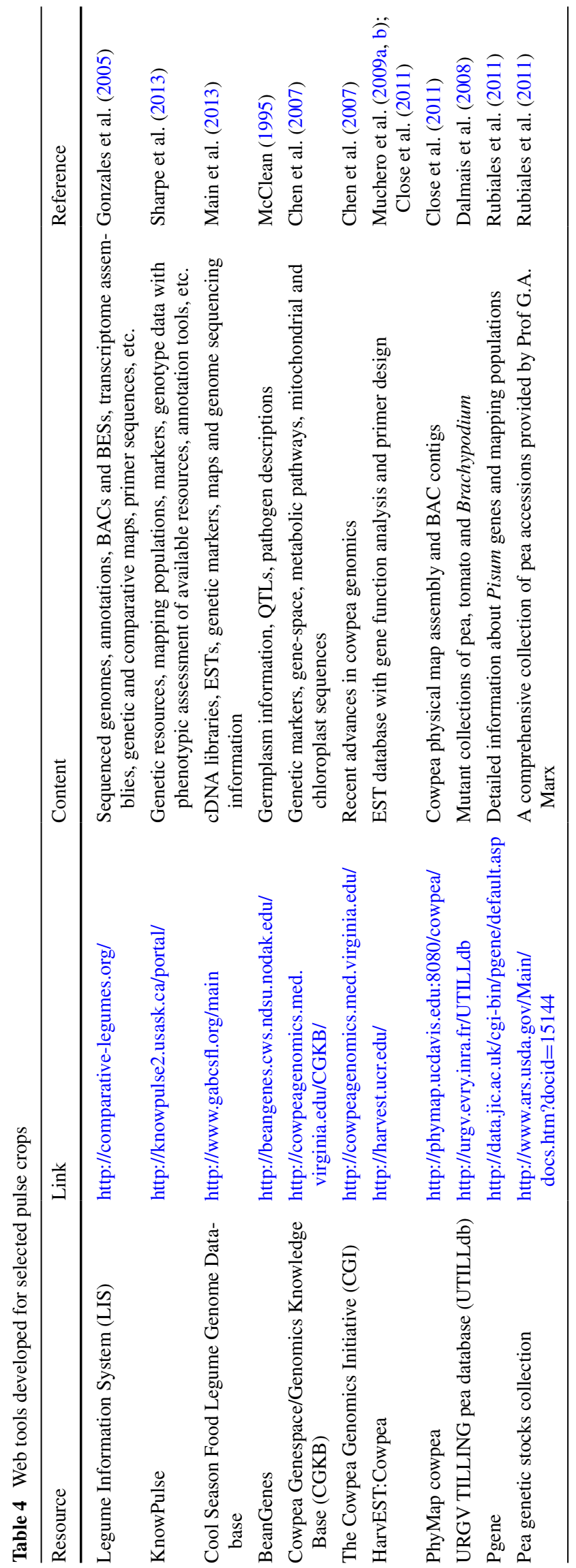




\section{Developing Web tools for community-oriented research}

With a deluge of omics information being generated worldwide, easy access to data remains one of the foremost challenges to large-scale integration of omics information into crop improvement (Main et al. 2013). The community-based approach has facilitated the development of several Web interfaces for various pulse crops, allowing storage and ensuing retrieval of data in a very systematic and user-friendly manner (Table 4). These databases offer a comprehensive view of the available genetic resources like mutant stocks/germplasm collections, genomic tools including BACs, BESs, markers, maps, QTLs and transcriptomic resources such as cDNA libraries and ESTs. Moreover, these Web tools integrate several other databases/browsers enabling comprehensive computational analyses for comparative genomics studies. For example, a popular legume Web resource namely Legume Information System (LIS) was developed by the National Center for Genome Resources (NCGR) and the United States Department of Agriculture (USDA), which incorporates several other databases and Web interfaces including SoyBase, CMap and comparative functional genomics browser (CFGB) (Gonzales et al. 2005). In the interest of the pulse research community, it is very essential to keep these websites updated with newer useful information.

\section{GAB in pulse crops: advancing from MAS to GS}

The establishment of marker-trait associations in these crops has opened new avenues for applying knowledgebased breeding, which focuses on crossing of genotypes and selection of appropriate offspring on the basis of QTL(s)/ marker(s) rather than relying entirely on phenotypic expression. Outstanding success stories on the deployment of the marker(s)/QTL(s) in routine breeding programme are available in several crops including rice, maize, wheat, pearl millet and mustard (Gupta et al. 2012a). In case of pulses, a relatively poor genomic infrastructure has prevailed for a long time, which has hampered the initial investments in GAB; however, recent developments in pulses genomics have led to initiation of several MAS projects.

It was the classic work by Karl Sax in common bean, which laid the foundation of modern theory of association between genetic markers and quantitative traits. He examined linkages of size differences with seed coat pattern and pigmentation (Sax 1923). Thenceforth, DNA markers have greatly contributed making MAS an integral component of pulse breeding. The utility of SCAR markers (MahSe2 and C42B) in discriminating Striga resistant and susceptible lines was successfully demonstrated in cowpea (Omoigui et al. 2012). In lentil, selection based on markers
UBC $227_{1290}$ (RAPD)/RB18 ${ }_{680}$ (SCAR) and OPO6 $_{1250}$ (RAPD) associated with Ascochyta blight and Anthracnose resistance, respectively, allowed identification of genotypes carrying resistance genes to both Ascochyta blight and Anthracnose (Tar'an et al. 2003a). Similarly, a robust CAPS marker was used for MAS in faba bean and exhibited $100 \%$ accuracy in distinguishing determinate and indeterminate genotypes in the $\mathrm{F}_{2}$ population (Verde Bonita' $\times 2$ N52) (Avila et al. 2006). Likewise, indirect selections using SCAR markers (linked with the genes: $z t-1$ and $z t-2$ ) were successful (accuracy up to $95 \%$ ) in discriminating high tannin-containing genotypes from genotypes with zero tannin content (Torres et al. 2010). The CAPS markers associated with low vicine and convicine content are also good candidates for practising MAS against these major anti-nutritional factors (Gutiérrez et al. 2006).

Marker-assisted back crossing (MABC) is the simplest way to introgress QTLs, particularly a finite number of QTL(s)/gene(s) experiencing strong and durable effects on the phenotype (Varshney et al. 2012; Xu et al. 2012b). Alternatively to capture multiple QTLs with smaller effects, the idea of marker-assisted recurrent selection (MARS) was propounded (Ribaut et al. 2010). Given the demerits of phenotypic recurrent selection (RS) like imprecise selection and lengthy breeding cycles, the MARS scheme offers a marker-aided refinement over RS in which selection and inter-mating are based on marker scores (Ribaut and Ragot 2007; Ribaut et al. 2010). Unlike MABC, MARS can be initiated without any prior knowledge of QTLs with the objective of discovering and harnessing the superior QTLs/alleles during the MARS scheme itself (Bernardo and Charcosset 2006). Empirical and simulation results obtained in maize, soybean and sunflower have encouraged the research community to extend MARS scheme to these pulse crops. For example, MARS programmes have been recently initiated in cowpea involving several populations, each derived from two elite parents (Huynh et al. 2014).

Sometimes, introgressed QTLs may not be able to reproduce the expected phenotype due to fresh genetic interactions that are established with the new genetic background (Grandillo and Tanksley 2005). Given the above-mentioned repercussion of QTL-background interactions, the advanced backcross QTL (AB-QTL) scheme was proposed that could facilitate detection as well as transfer of QTLs within the same mapping population. AB-QTL generates new prospects to explore the underutilized genetic variation contained in the CWRs (Tanksley and Nelson 1996). Though widely accepted in cereals like wheat, rice, barley and maize (Grandillo and Tanksley 2005), AB-QTL has not shown significant impacts in pulse crops. Among the various pulse crops, AB-QTL populations have been developed only in few crops like common bean and pigeonpea (Blair et al. 2006; Varshney et al. 2013a). In particular, the CWR-derived populations 
Fig. 2 Integrative genomics and breeding approach for accelerated genetic improvement in pulse crops. The figure depicts that methodological shifts in marker discovery/ genotyping and QTL mapping strategies have enhanced the throughput and resolution, respectively. Different kinds of mapping populations/association panels are used to establish the gene-trait associations. Concerning introgression of QTLs, MABC aims at transferring limited number of QTLs, while MARS enables accumulation of several QTLs. GS relies entirely on GEBV estimates and these estimates can be employed directly in breeding population for selection of superior genotypes. While practising $\mathrm{GAB}$, the magnitude of genetic gain increases in the following order: MABC $<$ MARS $<$ GS

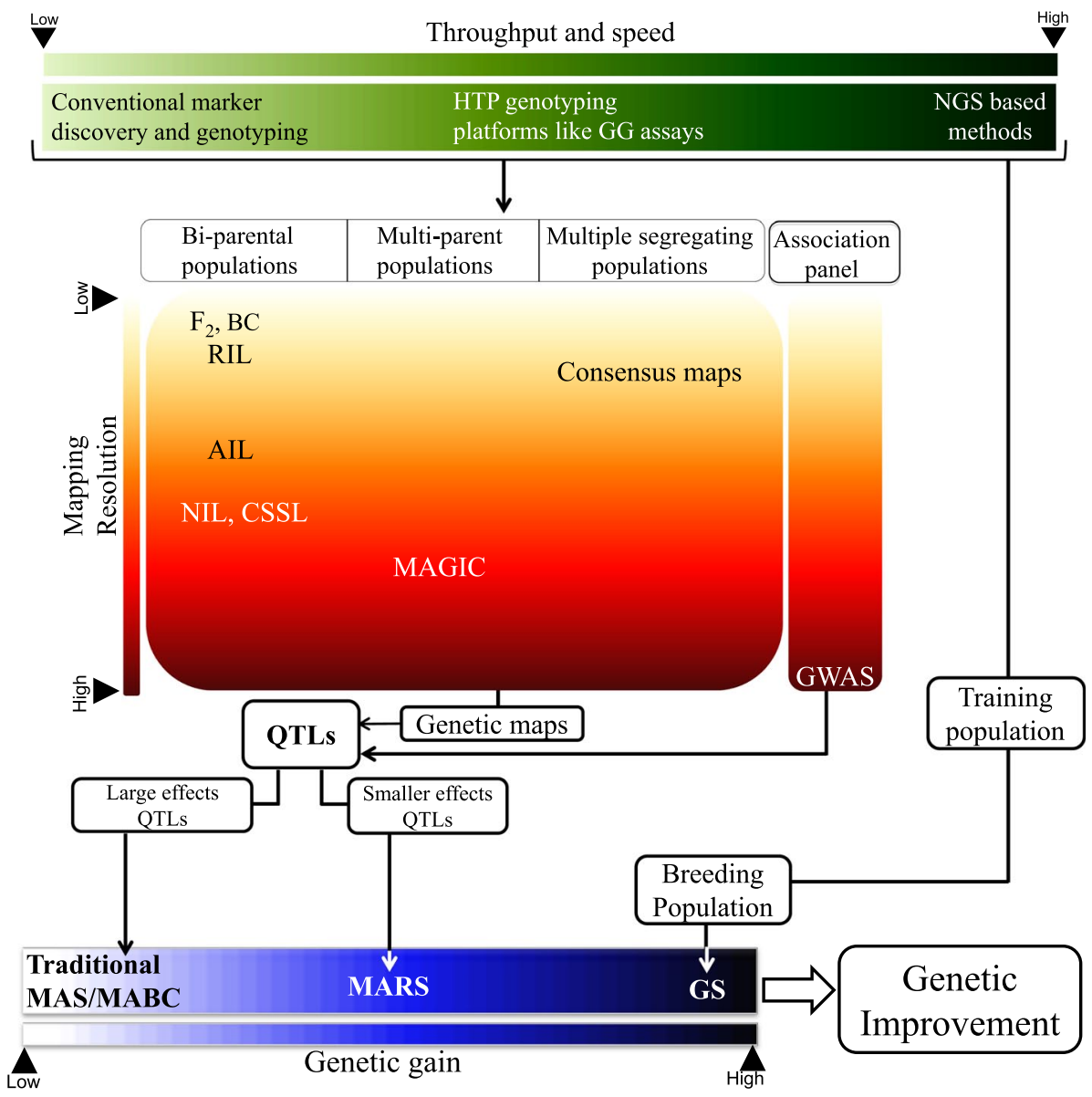

have great scope in improving crops that have suffered from severe domestication bottlenecks and extremely narrow genetic base in the primary gene pool. Owing to immense variability for domestication forms, pea is considered an excellent system to understand the genetic basis of changes that occurred during the process of domestication. A set of five broad-based genetic populations was established in pea using a wild ancestor ( $P$. sativum ssp. elatius) and primitive landrace ( $P$. sativum ssp. abyssinicum), and the investigation revealed important genes/QTLs for domestication-related traits that collectively represent a 'domestication syndrome' (Weeden 2007). The pulse crops have fairly less genetic diversity in the cultivated pool and, hence, development of such broad-based genetic populations is a highly desirable strategy to expand the genetic base.

In recent years, noteworthy changes were experienced in the throughput and accuracy of several genotyping platforms and NGS systems (Xu et al. 2012b). In parallel, a continued search for more efficient and high-throughput molecular breeding methods has resulted in the introduction of a novel approach for genetic improvement, in which selections are made on the basis of genomic estimated breeding values (GEBVs) (Meuwissen 2007). The GEBVs are calculated using genome-wide DNA marker information and choosing worthy individuals based on GEBV is referred to as genomic selection (GS) (Heffner et al. 2009; Meuwissen et al. 2001). In GS, high-density genotyping and phenome-level phenotyping are performed for training population. On the other hand, the candidate population (another component of GS) is used for genotyping only and eventually for selecting the superior individuals (Nakaya and Isobe 2012). As evident from the above description, no additional phenotyping is required for the candidate population. Hence, GS efficiently exploits the high-density marker data available at a reasonable cost, and at the same time it dramatically reduces the experimental cost by circumventing the need for repeated phenotyping (Heffner et al. 2009; Xu et al. 2012b). Keeping the recent genomics advances in view, a holistic approach for improvement of pulse crops has been illustrated in Fig. 2.

\section{Summary and perspectives}

To realize the enormous potential of genomic tools and technologies, it is essential that these tools should become 
an integral part of regular pulse breeding programmes so that all the accumulated resources and genomic knowledge could be translated into improved cultivars. The wide applicability of MAS has already been demonstrated in cowpea and pea, while in the case of lentil and faba bean it is in infancy stage. However, one encouraging fact is that exceptional progress has already been made in generating ample genomic resources in all the major pulse crops. To this end, the availability of reference genome sequences opens an exciting future for genomic-assisted pulse improvement. Though the prices of HTP genotyping and sequencing have come down to an affordable level, phenotyping of complex traits remains cumbersome, cost prohibitive and environmentally sensitive. Therefore, there is a compelling need to deploy modern molecular breeding methods such as MARS and GS that are able to reap maximum benefits from declining genotyping prices, while demanding the least (one-time) phenotyping. In addition, the recently developed NGS-based methods like WGRS/GBS/RADseq would efficiently extract valuable information from complex mapping resources such as MAGIC or NAM. Besides highresolution QTL mapping, nearly homozygous MAGIC lines have direct implications in variety development (see Bandillo et al. 2013). These advanced molecular breeding approaches thus represent the next generation of MAS that would greatly assist breeders to strengthen as well as reorient the pulse breeding programmes.

Acknowledgments $\mathrm{AB}$ would like to thank Dr. Kanwar L. Sahrawat, Adjunct Scientist, RP-Dry Land Cereals, International Crops Research Institute for the Semi-Arid Tropics (ICRISAT), Hyderabad, India, for providing detailed and constructive suggestions on the manuscript. AB, UCJ, IPS, DD, SKC and NN acknowledge the support from the Indian Council of Agricultural Research (ICAR), India. The authors from ICRISAT (MP and RKV) acknowledge the support from the Department of Biotechnology, Government of India, and CGIAR Generation Challenge Programme.

Conflict of interest The authors declare that there is no conflict of interest.

Open Access This article is distributed under the terms of the Creative Commons Attribution License which permits any use, distribution, and reproduction in any medium, provided the original author(s) and the source are credited.

\section{References}

Agarwal G, Jhanwar S, Priya P, Singh VK, Saxena MS, Parida SK, Garg R, Tyagi AK, Jain M (2012) Comparative analysis of kabuli chickpea transcriptome with desi and wild chickpea provides a rich resource for development of functional markers. PLoS One 7:e52443

Agbicodo EM, Fatokun CA, Bandyopadhyay R, Wydra K, Diop NN, Muchero W (2010) Identification of markers associated with bacterial blight resistance loci in cowpea (Vigna unguiculata (L.) Walp.). Euphytica 175:215-226
Akibode CS, Maredia M (2011) Global and regional trends in production, trade and consumption of food legume crops. Report submitted to the Standing Panel on Impact Assessment (SPIA) of the CGIAR Science Council, FAO, Rome

Aldemir SB, Sever T, Ates D, Yagmur B, Kaya HB, Temel HY, Kahriman A, Ozkan H, Tanyolac MB (2014) QTL mapping of genes controlling Fe uptake in lentil (Lens culinaris L.) seed using recombinant inbred lines. In Plant and Animal Genome Conference XXII P3360 (https://pag.confex.com/pag/xxii/webprog $\mathrm{ram} /$ Paper9689.html)

Alghamdi SS, Migdadi HM, Ammar MH, Paull JG, Siddique KHM (2012) Faba bean genomics: current status and future prospects. Euphytica 186:609-624

Andargie M, Pasquet RS, Gowda BS, Muluvi GM, Timko MP (2011) Construction of a SSR-based genetic map and identification of QTL for domestication traits using recombinant inbred lines from a cross between wild and cultivated cowpea ( $V$. unguiculata (L.) Walp.). Mol Breed 28:413-420

Andargie M, Pasquet RS, Muluvi GM, Timko MP (2013) Quantitative trait loci analysis of flowering time related traits identified in recombinant inbred lines of cowpea (Vigna unguiculata). Genome 56:289-294

Andargie M, Knudsen JT, Pasquet RS, Gowda BS, Muluvi GM, Timko MP (2014) Mapping of quantitative trait loci for floral scent compounds in cowpea (Vigna unguiculata L.). Plant Breed 133:92-100

Andeden EE, Derya M, Baloch FS, Kilian B, Ozkan H (2013) Development of SSR markers in lentil. In: Proceedings of plant and animal genome conference XXI P0351 (https://pag.confex.com/ pag/xxi/webprogram/Paper6565.html)

Antonio Blanco F, Meschini EF, Zanetti ME, Aguilar MO (2009) A small GTPase of the Rab family is required for root hair formation and preinfection stages of the common bean: Rhizobium symbiotic association. Plant Cell 21:2797-2810

Arbaoui M, Balko C, Link W (2008) Study of faba bean (Vicia faba L.) winter-hardiness and development of screening methods. Field Crop Res 106:60-67

Arumuganathan K, Earle ED (1991) Nuclear DNA content of some important plant species. Mol Biol Report 9:208-221

Aryamanesh N, Zeng Y, Byrne O, Hardie DC, Al-Subhi AM, Khan T, Siddique KHM, Yan G (2014) Identification of genome regions controlling cotyledon, pod wall/seed coat and pod wall resistance to pea weevil through QTL mapping. Theor Appl Genet 127:489-497

Atif RM, Patat-Ochatt EM, Svabova L, Ondrej V, Klenoticova H, Jacas L, Griga M, Ochatt SJ (2013) Gene transfer in legumes. In: Lüttge U, Beyschlag W, Francis D, Cushman J (eds) Progress in botany. Springer, Heidelberg, pp 37-100

Aubert G, Morin J, Jacquin F, Loridon K, Quillet MC, Petit A, Lejeune-Hénaut I, Huguet T, Burstin J (2006a) Functional mapping in pea, as an aid to the candidate gene selection and for investigating synteny with the model legume Medicago truncatula. Theor Appl Genet 112:1024-1041

Aubert G, Morin J, Jacquin F, Loridon K, Quillet MC, Petit A, Rameau C, Lejeune-Hénaut I, Huguet T, Burstin J (2006b) Functional mapping in pea, as an aid to the candidate gene selection and for investigating synteny with the model legume Medicago truncatula. Theor Appl Genet 112:1024-1041

Avila CM, Sillero JC, Rubiales D, Moreno MT, Torres AM (2003) Identification of RAPD markers linked to the $U v f-1$ gene conferring hypersensitive resistance against rust (Uromyces viciaefabae) in Vicia faba L. Theor Appl Genet 107:353-358

Avila CM, Satovic Z, Sillero JC, Rubiales D, Moreno MT, Torres AM (2004) Isolate and organ-specific QTLs for ascochyta blight resistance in faba bean. Theor Appl Genet 108:1071-1078 
Avila MC, Satovi Z, Sillero JC, Nadal S, Rubiales D, Moreno MT, Torres AM (2005) QTL detection for agronomic traits in faba bean (Vicia faba L.). Agric Conspec Sci 3:65-73

Avila CM, Nadal S, Moreno MT, Torres AM (2006) Development of a simple PCR-based marker for the determination of growth habit in Vicia faba L. using a candidate gene approach. Mol Breed 17:185-190

Avila CM, Atienza SG, Moreno MT, Torres AM (2007) Development of a new diagnostic marker for growth habit selection in faba bean (Vicia faba L.) breeding. Theor Appl Genet 115:1075-1082

Bakshi S, Sadhukhan A, Mishra S, Sahoo L (2011) Improved Agrobacterium-mediated transformation of cowpea via sonication and vacuum infiltration. Plant Cell Rep 30:2281-2292

Bakshi S, Saha B, Roy NK, Mishra S, Panda SK, Sahoo L (2012) Successful recovery of transgenic cowpea (Vigna unguiculata) using the 6-phosphomannose isomerase gene as the selectable marker. Plant Cell Rep 31:1093-1103

Bandillo N, Raghavan C, Muyco PA et al (2013) Multi-parent advanced generation inter-cross (MAGIC) populations in rice: progress and potential for genetics research and breeding. Rice 6:11

Bardner R (1983) Pests of Vicia faba L. other than aphids and nematodes. In: Hebblethwaite PD (ed) The faba bean (Vicia faba L.), Butterworths, London, UK, pp 371-390

Barrera-Figueroa BE, Gao L, Diop NN, Wu Z, Ehlers JD, Roberts PA, Close TJ, Zhu JK, Liu R (2011) Identification and comparative analysis of drought-associated micro RNAs in two cowpea genotypes. BMC Plant Biol 11:127

Bernardo R, Charcosset A (2006) Usefulness of gene information in marker-assisted recurrent selection: a simulation appraisal. Crop Sci 46:614-621

Blair MW, Iriarte G, Beebe S (2006) QTL analysis of yield traits in an advanced backcross population derived from a cultivated Andean wild common bean (Phaseolus vulgaris L.) cross. Theor Appl Genet 112:1149-1163

Blixt S (1972) Mutation genetics in Pisum. Agric Hort Genet 30:1-293

Bohra A (2013) Emerging paradigms in genomics-based crop improvement. Sci World J 585467:17

Bond DA (1989) Prospects for commercialization of $F_{1}$ hybrid field beans Vicia faba L. Euphytica 41:81-86

Bonfim K, Faria JC, Nogueira EO, Mendes EA, Aragão FJ (2007) RNAi-mediated resistance to bean golden mosaic virus in genetically engineered common bean (Phaseolus vulgaris). Mol Plant Microbe Interact 20:717-726

Bordat A, Savois V, Nicolas M, Salse J, Chauveau A, Bourgeois M, Potier J, Houtin H, Rond C, Murat F, Marget P, Aubert G, Burstin J (2011) Translational genomics in legumes allowed placing in silico 5460 unigenes on the pea functional map and identified candidate genes in Pisum sativum L. Genes Genome Genet 1:93-103

Boukar O, Kong L, Singh BB, Murdock L, Ohm HW (2004) AFLP and AFLP-derived SCAR markers associated with Striga gesnerioides resistance in cowpea. Crop Sci 44:1259-1264

Bourion V, Rizvi SM, Fournier S, de Larambergue H, Galmiche F, Marget P, Duc G, Burstin J (2010) Genetic dissection of nitrogen nutrition in pea through a QTL approach of root, nodule and shoot variability. Theor Appl Genet 121:71-86

Briñez B, Blair MW, Kilian A, Carbonell SAM, Chiorato AF, Rubiano LB (2012) A whole genome DArT assay to assess germplasm collection diversity in common beans. Mol Breed 30: 181-193

Broughton WJ, Hernandez G, Blair M, Beebe S, Gepts P, Vanderleyden J (2003) Beans (Phaseolus spp.): model food legumes. Plant Soil 252:55-128
Burstin J, Deniot G, Potier J, Weinachter C, Aubert G, Baranger A (2001) Microsatellite polymorphism in Pisum sativum. Plant Breed 120:311-317

Cannon SB, May GD, Jackson SA (2009) Three sequenced legume genomes and many crop species: rich opportunities for translational genomics. Plant Physiol 151:970-977

Cavanagh C, Morell M, Mackay I, Powell W (2008) From mutations to MAGIC: resources for gene discovery, validation and delivery in crop plants. Curr Opin Plant Biol 11:215-221

Chandra A, Pental D (2003) Regeneration and genetic transformation of grain legumes: an overview. Curr Sci 84:381-387

Chen YL, Huang R, Xiao YM, Lu P, Chen J, Wang XC (2004) Extracellular calmodulin-induced stomatal closure is mediated by heterotrimeric $\mathrm{G}$ protein and $\mathrm{H}_{2} \mathrm{O}_{2}$. Plant Physiol 136:4096-4103

Chen X, Laudeman TW, Rushton PJ, Spraggins TA, Timko MP (2007) CGKB: an annotation knowledge base for cowpea (Vigna unguiculata $\mathrm{L}$.) methylation filtered genomic genespace sequences. BMC Bioinform 8:129

Chopra R, Prabhakar A, Singh N, Saini R (2011) In vitro regeneration and sonication assisted Agrobacterium tumefaciens (SAAT) mediated transformation in Indian cultivars of lentil (Lens culinaris Medik.). 5th Chandigarh Science Congress, Chandigarh, India, pp. 10

Chowdhury MA, Andrahennadi CP, Slinkard AE, Vandenberg A (2001) RAPD and SCAR markers for resistance to ascochyta blight in lentil. Euphytica 118:331-337

Close TJ, Luo M, Lonardi S, Alpert M et al. (2011) Genome resources for cowpea genotype IT97 K-499-35. In: Proceedings of plant and animal genome conference XIX P028 (http://www.intl-pag.org/19/abstracts/P01_PAGXIX_028.html)

Cockram J, White DL, Zuluaga D et al (2010) Genome-wide association mapping to candidate polymorphism resolution in the unsequenced barley genome. Proc Nat Acad Sci USA 107:21611-21616

Collard BCY, Jahufer MZZ, Brouwer JB, Pang ECK (2005) An introduction to markers, quantitative trait loci (QTL) mapping and marker-assisted selection for crop improvement: the basic concepts. Euphytica 142:169-196

Cook JP, McMullen MD, Holland JB, Tian F, Bradbury P, Ross-Ibarra J, Buckler ES, Flint-Garcia SA (2012) Genetic architecture of maize kernel composition in the nested association mapping and inbred association panels. Plant Physiol 158:824-834

Córdoba JM, Chavarro C, Schlueter JA, Jackson SA, Blair MW (2010) Integration of physical and genetic maps of common bean through BAC-derived microsatellite markers. BMC Genom 11:436

Cottage A, Gostkiewicz K, Thomas JE, Borrows R, Torres AM, O'Sullivan DM (2012) Heterozygosity and diversity analysis using mapped SNPs in a faba bean inbreeding programme. Mol Breed 30:1799-1809

Coyne CJ, McClendon MT, Walling JG et al (2007) Construction and characterization of two bacterial artificial chromosome libraries of pea (Pisum sativum L.) for the isolation of economically important genes. Genome 50:871-875

Cruz-Izquierdo S, Avila CM, Satovic Z, Palomino C, Gutiérrez N, Ellwood SR, Phan HT, Cubero JI, Torres AM (2012) Comparative genomics to bridge Vicia faba with model and closely-related legume species: stability of QTLs for flowering and yieldrelated traits. Theor Appl Genet 125:1767-1782

Cubero JI, Nadal S (2005) Faba bean (Vicia faba L.). In: Singh RJ, Jauhar PP (eds) Genetic resources, chromosome engineering and crop improvement, CRC Press p 164-180

Dalmais M, Schmidt J, Le Signor C et al (2008) UTILLdb, a Pisum sativum in silico forward and reverse genetics tool. Genome Biol 9:R43 
Davey JW, Hohenlohe PA, Etter PD, Boone JQ, Catchen JM, Blaxter ML (2011) Genome-wide genetic marker discovery and genotyping using next-generation sequencing. Nat Rev Genet $12: 499-510$

De Caire J, Coyne JC, Brumett S, Shultz JL (2011) Additional pea EST-SSR markers for comparative mapping in pea (Pisum sativum L.). Plant Breed 131:122-126

De la Puente R, García P, Polanco C, Pérez de la Vega M (2013) An improved intersubspecific genetic map in Lens including functional markers. Span J Agric Res 11:1

D’Erfurth I, Le Signor C, Aubert G, Sanchez M, Vernoud V, Darchy B et al (2012) A role for an endosperm-localized subtilase in the control of seed size in legumes. New Phytol 196:738-751

Deschamps S, Llaca V, May GD (2012) Genotyping-by-sequencing in plants. Biology 1:460-483

Deulvot C, Charrel H, Marty A, Jacquin F, Donnadieu C, LejeuneHénaut I, Burstin J, Aubert G (2010) Highly-multiplexed SNP genotyping for genetic mapping and germplasm diversity studies in pea. BMC Genom 11:468

Díaz-Ruiz R, Satovic Z, Avila CM, Alfaro CM, Gutiérrez MV, Torres AM, Román B (2009a) Confirmation of QTLs controlling Ascochyta fabae resistance in different generations of faba bean (Vicia faba L.). Crop Pasture Sci 60:353-361

Díaz-Ruiz R, Torres A, Gutiérrez MV, Rubiales D, Cubero JI, Kharrat M, Satovic Z, Román B (2009b) Mapping of quantitative trait loci controlling Orobanche foetida Poir. resistance in faba bean (Vicia faba L.). Afr J Biotechnol 8:2718-2724

Dietrich P, Sanders D, Hedrich R (2001) The role of ion channels in light-dependent stomatal opening. J Exp Bot 52:1959-1967

Dirlewanger E, Isaac P, Ranade S, Belajouza M, Cousin R, Devienne D (1994) Restriction fragment length polymorphism analysis of loci associated with disease resistance genes and developmental traits in Pisum sativum L. Theor Appl Genet 88:17-27

Dixon GR (1987) Powdery mildew of vegetables and allied crops. In: Speaure DM (ed) Powdery mildew. Academic Press, San Diego, pp 502-506

Duarte J, Rivière N, Baranger A et al (2014) Transcriptome sequencing for high throughput SNP development and genetic mapping in pea. BMC Genom 15:126

Dumont E, Fontaine V, Vuylsteker C et al (2009) Association of sugar content QTL and PQL with physiological traits relevant for frost damage resistance in pea under field and controlled conditions. Theor Appl Genet 118:1561-1571

Durán Y, Fratini R, García P, Pérez de la Vega M (2004) An intersubspecific genetic map of Lens. Theor Appl Genet 108:1265-1273

Eapen E (2008) Advances in development of transgenic pulse crops. Biotechnol Adv 26:162-168

Ek M, Eklund M, von Post R, Dayteg C, Henriksson T, Weibull P, Ceptilis A, Issac P, Tuvesson S (2005) Microsatellite markers for powdery mildew resistance in pea (Pisum sativum L.). Hereditas 142:86-91

Ellis THN, Turner L, Hellens RP, Lee D, Harker CL, Enard C, Domoney C, Davies DR (1992) Linkage maps in pea. Genetics 130:649-663

Ellwood SR, Phan HTT, Jordan M, Torres AM, Avila CM, Cruz-Izquierdo S, Oliver RP (2008) Construction of a comparative genetic map in faba bean (Vicia faba L.); conservation of genome structure with Lens culinaris. BMC Genom 9:380

Eujayl I, Baum M, Powell W, Erskine W, Pehu E (1998) A genetic linkage map of lentil (Lens sp.) based on RAPD and AFLP markers using recombinant inbred lines. Theor Appl Genet 97:83-89

Eujayl I, Erskine W, Baum M, Pehu E (1999) Inheritance and linkage analysis of frost injury in lentil. Crop Sci 39:639-642

FAO (2012) Food and Agricultural Organization of the United Nation, FAO Statistical Database. (http://faostat.fao.org)
Farrar K, Donnison IS (2007) Construction and screening of BAC libraries made from Brachypodium genomic DNA. Nat Protoc 2:1661-1674

Fatokun CA, Menancio-Hautea DI, Danesh D, Young ND (1992) Evidence for orthologous seed weight genes in cowpea and mungbean based on RFLP mapping. Genetics 132:841-846

Fedoruk M (2013) Linkage and association mapping of seed size and shape in lentil. Thesis (Masters of Science), University of Saskatchewan, Saskatoon

Fedoruk MJ, Vandenberg A, Bett KE (2013) QTL analysis of seed quality characteristics in lentil (Lens culinaris ssp. culinaris Medik.) using SNP markers. Plant Genome 6:3

Fondevilla S, Satovic Z, Rubiales D, Moreno MT, Torres AM (2008) Mapping of quantitative trait loci for resistance to Mycosphaerella pinodes in Pisum sativum subsp. syriacum. Mol Breed 21:439-454

Fondevilla S, Fernández-Aparicio M, Satovic Z, Emeran AA, Torres AM, Moreno MT, Rubiales D (2010) Identification of quantitative trait loci for specific mechanisms of resistance to Orobanche crenata Forsk. in pea (Pisum sativum L.). Mol Breed 25:259-272

Ford R, Pang ECK, Taylor PWJ (1999) Genetics of resistance to ascochyta blight (A. lentis) of lentil and the identification of closely linked RAPD markers. Theor Appl Genet 98:93-98

Ford R, Rubeena, Redden RJ, Materne M, Taylor PWJ (2007) Lentil. In: Kole C (ed) Genome mapping and molecular breeding in plants: pulses, sugar and tuber crops. Springer, Berlin, pp 91-104

Franssen SU, Shrestha RP, Bräutigam A, Bornberg-Bauer E, Weber APM (2011) Comprehensive transcriptome analysis of the highly complex Pisum sativum genome using next generation sequencing. BMC Genom 12:227

Fratini R, Durán Y, García P, Pérez de la Vega M (2007) Identification of quantitative trait loci (QTL) for plant structure, growth habit and yield in lentil. Span J Agric Res 5:348-356

Galeano CH, Cortés AJ, Fernández AC, Soler Á, Franco-Herrera N, Makunde G, Vanderleyden J, Blair MW (2012) Gene-based single nucleotide polymorphism markers for genetic and association mapping in common bean. BMC Genet 13:48

Gao XQ, Li CG, Wei PC, Zhang XY, Chen J, Wang XC (2005) The dynamic changes of tonoplasts in guard cells are important for stomatal movement in Vicia faba. Plant Physiol 139:1207-1216

Gaur PM, Jukanti AK, Varshney RK (2012) Impact of genomic technologies on chickpea breeding strategies. Agronomy 2:199-221

Gelvin SB (2003) Agrobacterium-mediated plant transformation: the biology behind the "gene-jockeying" tool. Microbiol Mol Biol Rev 67:16-37

Gepts P, Beavis WD, Brummer EC, Shoemaker RC, Stalker HT, Weeden NF, Young ND (2005) Legumes as a model plant family: genomics for food and feed report of the cross-legume advances through genomics conference. Plant Physiol 137:1228-1235

Gepts P, Aragão F, de Barros E et al (2008) Genomics of Phaseolus beans, a major source of dietary protein and micronutrients in the tropics. In: Moore P, Ming R (eds) Genomics of tropical crop plants. Springer, Berlin, pp 113-143

Gilchrist EJ, Haughn GW (2005) TILLING without a plough: a new method with applications for reverse genetics. Curr Opin Plant Biol 8:211-215

Gilpin BF, McCallum JA, Frew TJ, Timmerman-Vaughan GM (1997) A linkage map of the pea (Pisum sativum L.) genome containing cloned sequences of known function and expressed sequence tags (ESTs). Theor Appl Genet 95:1289-1299

Gnanasambandam A, Paull J, Torres A, Kaur S, Leonforte T, Li H, Zong X, Yang T, Materne M (2012) Impact of molecular technologies on faba bean (Vicia faba L.) breeding strategies. Agronomy 2:132-166 
Godfray HC, Beddington JR, Crute IR, Haddad L, Lawrence D, Muir JF, Pretty J, Robinson S, Thomas SM, Toulmin C (2010) Food security: the challenge of feeding 9 billion people. Science 327:812-818

Gonzales MD, Archuleta E, Farmer A, Gajendran K, Grant D, Shoemaker R, Beavis WD, Waugh ME (2005) The legume information system (LIS): an integrated information resource for comparative legume biology. Nucleic Acids Res 33:D660-D665

Grandillo S, Tanksley SD (2005) Advanced backcross QTL analysis: results and perspectives. In: Tuberosa R, Phillips RL, Gale M (eds) The wake of the double helix: from the green revolution to the gene revolution. Edizioni Avenue Media, Italy, pp 115-132

Gressel J, Hanafi A, Head G, Marasas W, Obilana B, Ochanda J, Souissi T, Tzotzos G (2004) Major heretofore intractable biotic constraints to African food security that may be amenable to novel biotechnological solutions. Crop Prot 23:661-689

Griga MJ, Stejskal J, Beber K (1995) Analysis of tissue culture derived variation in pea (Pisum sativum L.): preliminary results. Euphytica 85:335-339

Grønlund M, Olsen A, Johansen EI, Jakobsen I (2010) Protocol: using virus-induced gene silencing to study the arbuscular mycorrhizal symbiosis in Pisum sativum. Plant Methods 6:28

Gupta SK, Gopalakrishna T (2010) Development of unigene-derived SSR markers in cowpea (Vigna unguiculata) and their transferability to other Vigna species. Genome 53:508-523

Gupta PK, Balyan HS, Kumar S, Dhariwal R, Jaiswal V, Tyagi S, Agarwal P, Gahlaut V, Kumari S (2012a). Marker-assisted selection for improvement of some major crops in India. In: Proceedings of plant and animal genomes conference XX W542. (https: //pag.confex.com/pag/xx/webprogram/Paper3107.html)

Gupta M, Verma B, Kumar N, Chahota RK, Rathour R, Sharma SK, Bhatia S, Sharma T (2012b) Construction of intersubspecific molecular genetic map of lentil based on ISSR, RAPD and SSR markers. J Genet 91:279-287

Gupta D, Taylor PWJ, Inder P, Phan HTT, Ellwood SR, Mathur PN, Sarker A, Ford R (2012c) Integration of EST-SSR markers of Medicago truncatula into intraspecific linkage map of lentil and identification of QTL conferring resistance to ascochyta blight at seedling and pod stages. Mol Breed 30:429-439

Gutiérrez N, Avila CM, Duc G, Marget P, Suso MJ, Moreno MT, Torres AM (2006) CAPs markers to assist selection for low vicine and convicine content in faba bean (Vicia faba L.). Theor Appl Genet 114:59-66

Gutiérrez N, Avila C, Rodriguez-Suarez C, Moreno M, Torres A (2007) Development of SCAR markers linked to a gene controlling absence of tannins in faba bean. Mol Breed 19:305-314

Gutiérrez N, Avila CM, Moreno MT, Torres AM (2008) Development of SCAR markers linked to $z t-2$, one of the genes controlling absence of tannins in faba bean. Aust J Agric Res 59:62-68

Gutiérrez N, Palomino C, Satovic Z et al (2013) QTLs for Orobanche spp. resistance in faba bean: identification and validation across different environments. Mol Breed 32:909-922

Hall AE (2004) Breeding for adaptation to drought and heat in cowpea. Europ J Agron 21:447-454

Hall KJ, Parker JS, Ellis THN (1997) The relationship between genetic and cytogenetic maps of pea I. Standard and translocation karyotypes. Genome 40:744-754

Hall AE, Cisse N, Thiaw S et al (2003) Development of cowpea cultivars and germplasm by the Bean/Cowpea CRSP. Field Crop Res 82:103-134

Hamon C, Baranger A, Coyne CJ et al (2011) New consistent QTL in pea associated with partial resistance to Aphanomyces euteiches in multiple French and American environments. Theor Appl Genet 123:261-281

Hamon C, Coyne CJ, McGee RJ et al (2013) QTL meta-analysis provides a comprehensive view of loci controlling partial resistance to Aphanomyces euteiches in four sources of resistance in pea. BMC Plant Biol 13:45

Hamwieh A, Udapa SM, Choumane W, Sarker A, Dreyer F, Jung C, Baum M (2005) A genetic linkage map of lentil based on microsatellite and AFLP markers and localization of fusarium vascular wilt resistance. Theor Appl Genet 110:669-677

Hamwieh A, Udupa SM, Sarker A, Jung C, Baum M (2009) Development of new microsatellite markers and their application in the analysis of genetic diversity in lentils. Breed Sci 59:77-86

Hanafy M, Pickardt T, Kiesecker H, Jacobsen HJ (2005) Agrobacterium-mediated transformation of faba bean (Vicia faba L.) using embryo axes. Euphytica 142:227-236

Hanstein SM, Felle $\mathrm{HH}$ (2002) $\mathrm{CO}_{2}$-triggered chloride release from guard cells in intact fava bean leaves. Kinetics of the onset of stomatal closure. Plant Physiol 130:940-950

Heffner EL, Sorrells ME, Jannink JL (2009) Genomic selection for crop improvement. Crop Sci 49:1-12

Hiremath PJ, Kumar A, Penmetsa RV et al (2012) Large-scale development of cost-effective SNP marker assays for diversity assessment and genetic mapping in chickpea and comparative mapping in legumes. Plant Biotechnol J 10:716-732

Hofer J, Turner L, Moreau C, Ambrose M, Isaac P, Butcher S, Weller J, Dupin A, Dalmais M, Le Signor C, Bendahmane A, Ellis N (2009) Tendril-less regulates tendril formation in pea leaves. Plant Cell 21:420-428

Huynh BL, Close TJ, Drabo I et al. (2014) Genomic resources applied to marker-assisted breeding in cowpea. In: Proceedings of plant and animal genome conference XXII W351. (https://pag.confex .com/pag/xxii/webprogram/Paper12656.html)

Imelfort M, Edwards D (2009) De novo sequencing of plant genomes using second generation technologies. Brief Bioinform 10:609-618

Irzykowska L, Wolko B (2004) Interval mapping of QTLs controlling yield-related traits and seed protein conte in Pisum sativum. J Appl Genet 45:297-306

Kahraman A, Kusmenoglu I, Aydin N, Aydogan A, Erskine W, Muehlbauer FJ (2004) QTL mapping of winter hardiness genes in lentil. Crop Sci 44:13-22

Kahraman A, Demirel U, Ozden M, Muehlbauer FJ (2010) Mapping of QTLs for leaf area and the association with winter hardiness in fall-sown lentil. Afr J Biotechnol 9:8515-8519

Kamara AY, Ajeigbe HA, Omoigui LO, Chikoye D (2012) Intensive cereal-legume-livestock systems in West African dry Savannas. In: Proceedings of issues in tropical agriculture eco-efficiency: from vision to reality. CIAT $\mathrm{p} 1-17$

Kami J, Poncet V, Geffroy V, Gepts P (2006) Development of four phylogenetically-arrayed BAC libraries and sequence of the APA locus in Phaseolus vulgaris. Theor Appl Genet 112:987-998

Kaur S, Cogan NO, Pembleton LW, Shinozuka M, Savin KW, Materne M, Forster JW (2011) Transcriptome sequencing of lentil based on second-generation technology permits largescale unigene assembly and SSR marker discovery. BMC Genom 12:265

Kaur S, Pembleton LW, Cogan NO, Savin KW, Leonforte T, Paull J, Materne M, Forster JW (2012) Transcriptome sequencing of field pea and faba bean for discovery and validation of SSR genetic markers. BMC Genom 13:104

Kaur S, Cogan NO, Stephens A, Noy D, Butsch M, Forster JW, Materne M (2013) EST-SNP discovery and dense genetic mapping in lentil (Lens culinaris Medik.) enable candidate gene selection for boron tolerance. Theor Appl Genet 127:703-713

Kaur S, Kimber RBE, Cogan NOI, Materne M, Forster JW, Paull JG (2014) SNP discovery and high-density genetic mapping in faba bean (Vicia faba L.) permits identification of QTLs for ascochyta blight resistance. Plant Sci 217-218:47-55 
Kelly JD, Gepts P, Miklas PN, Coyne DP (2003) Tagging and mapping of genes and QTL and molecular marker-assisted selection for traits of economic importance in bean and cowpea. Field Crop Res 82:135-154

Khera P, Upadhyaya HD, Pandey MK et al (2013) SNP-based genetic diversity in the reference set of peanut (Arachis spp.) by developing and applying cost-effective KASPar genotyping assays. Plant Genome 6:1-11

Knox MR, Ellis THN (2002) Excess heterozygosity contributes to genetic map expansion in pea recombinant inbred populations. Genetics 162:861-873

Kongjaimun A, Kaga A, Tomooka N, Somta P, Shimizu T, Shu Y, Isemura T, Vaughan DA, Srinives P (2012a) An SSR-based linkage map of yardlong bean (Vigna unguiculata (L.) Walp. subsp. unguiculata sesquipedalis group) and QTL analysis of pod length. Genome 55:81-92

Kongjaimun A, Kaga A, Tomooka N, Somta P, Vaughan DA, Srinives $P(2012 b)$ The genetics of domestication of yardlong bean, Vigna unguiculata (L.) Walp. ssp. unguiculata cv.-gr. sesquipedalis. Ann Bot 109:1185-1200

Kongjaimun A, Somta P, Tomooka N, Kaga A, Vaughan DA, Srinives P (2013) QTL mapping of pod tenderness and total soluble solid in yardlong bean (Vigna unguiculata (L.) Walp. subsp. unguiculata cv.-gr. sesquipedalis). Euphytica 189:217-223

Korte A, Farlow A (2013) The advantages and limitations of trait analysis with GWAS: a review. Plant Methods 9:29

Kudapa H, Bharti AK, Cannon SB et al (2012) A comprehensive transcriptome assembly of pigeonpea (Cajanaus cajan L.) using Sanger and Second-generation sequencing platforms. M Plant 5:1020-1028

Kumar S, Banks TW, Cloutier S (2012) SNP discovery through nextgeneration sequencing and its applications. Int J Plant Genomics 2012:15 (Article ID 831460)

Kwon SJ, Brown AF, Hu J, McGee R, Watt C, Kisha T, TimmermanVaughan G, Grusak M, McPhee KE, Coyne CJ (2012) Genetic diversity, population structure and genome-wide markertrait association analysis emphasizing seed nutrients of the USDA pea (Pisum sativum L.) core collection. Genes Genom 34:305-320

Kwon SJ, Smýkal P, Hu J, Wang M, Kim SJ, McGee RJ, McPhee K, Coyne CJ (2013) User-friendly markers linked to Fusarium wilt race 1 resistance $F w$ gene for marker-assisted selection in pea. Plant Breed 132:642-648

Laucou V, Haurogne' K, Ellis N, Rameau C (1998) Genetic mapping in pea. 1. RAPD-based genetic linkage map of Pisum sativum. Theor Appl Genet 97:905-915

Leonforte A, Sudheesh S, Cogan NOI, Salisbury PA, Nicolas ME, Materne M, Forster JW, Kaur S (2013) SNP marker discovery, linkage map construction and identification of QTLs for enhanced salinity tolerance in field pea (Pisum sativum L.). BMC Plant Biol 13:161

Li CD, Fatokun CA, Ubi B, Singh BB, Scoles GJ (2001) Determining genetic similarities and relationships among cowpea breeding lines and cultivars by microsatellite markers. Crop Sci 41:189-197

Li-Juan L, Zhao-hai Y, Zhow-jie Z, Ming-shi X, Han-qing Y (1993) Faba bean in China: state-of-the-art review. In: Proceedings of International Center for Agricultural Research in the Dry Areas Aleppo, Syria

Link W, Schill B, Kittlitz EV (1996) Breeding for wide adaptation in faba bean. Euphytica 92:185-190

Link W, Ederer W, Gumber RK, Melchinger AE (1997) Detection and characterization of two new CMS systems in faba bean (Vicia faba). Plant Breed 116:158-162

Loridon K, McPhee K, Morin J, Dubreuil P, Pilet-Nayel ML, Aubert G, Rameau C, Baranger A, Coyne C, Lejeune-Hènaut I, Burstin
J (2005) Microsatellite marker polymorphism and mapping in pea (Pisum sativum L.). Theor Appl Genet 111:1022-1031

Lucas MR, Diop NN, Wanamaker S, Ehlers JD, Roberts PA, Close TJ (2011) Cowpea soybean synteny clarified through an improved genetic map. Plant Genome 4:218-219

Lucas MR, Ehlers JD, Roberts PA, Close TJ (2012) Markers for quantitative inheritance of resistance to foliar thrips in cowpea. Crop Sci 52:2075-2081

Lucas MR, Ehlers JD, Huynh BL, Diop NN, Roberts PA, Close TJ (2013a) Markers for breeding heat-tolerant cowpea. Mol Breed 31:529-536

Lucas MR, Huynh BL, da Silva Vinholes P, Cisse N, Drabo I, Ehlers JD, Roberts PA, Close TJ (2013b) Association studies and legume synteny reveal haplotypes determining seed size in Vigna unguiculata. Front Plant Sci 4:95

Luo T, Luo S, Araújo WL, Schlicke H, Rothbart M, Yu J, Fan T, Fernie AR, Grimm B, Luo M (2013) Virus-induced gene silencing of pea $C H L I$ and $C H L D$ affects tetrapyrrole biosynthesis, chloroplast development and the primary metabolic network. Plant Physiol Bioch 65:17-26

Ma Y, Bao S, Yang T, Hu J, Guan J, He Y, Wang X, Wan Y, Sun X, Jiang J, Gong C, Zong X (2013) Genetic linkage map of Chinese native variety faba bean (Vicia faba L.) based on simple sequence repeat markers. Plant Breed 132:397-400

Macas J, Neumann P, Navrátilová A (2007) Repetitive DNA in the pea (Pisum sativum L.) genome: comprehensive characterization using 454 sequencing and comparison to soybean and Medicago truncatula. BMC Genom 8:427

Mackay I, Powell W (2007) Methods for linkage disequilibrium mapping in crops. Trends Plant Sci 12:57-63

Madrid E, Palomino C, Plötner A, Horres R, Rotter B, Winter P, Krezdorn N, Torres A (2013) DeepSuperSage analysis of the Vicia faba transcriptome in response to Ascochyta fabae infection. Phytopathol Mediterr 52:166-182

Main D, Cheng CH, Ficklin SP, Jung S, Zheng P, Coyne JC, McGee R, Mokaitis K (2013) The cool season food legume database: an integrated resource for basic, translational and applied research. In: Proceedings of plant and animal genomes conference XXI W215 (https://pag.confex.com/pag/xxi/webprogram/ Paper6640.html)

McCallum J, Timmerman-Vaughan G, Frew T, Russell A (1997) Biochemical and genetic linkage analysis of green seed color in field pea. J Amer Hort Sci 122:218-225

McCallum CM, Comai L, Greene EA, Henikoff S (2000) Targeting induced local lesions in genomes (TILLING) for plant functional genomics. Plant Physiol 123:439-442

McClean PE (1995) BeanGenes-A Phaseolus/Vigna sp. Database. Ann Report Bean Imp Coop 38:13-14

McMullen MD, Kresovich S, Villeda HS et al (2009) Genetic properties of the maize nested association mapping population. Science 325:737-740

McPhee KE (2007) Pea. In: Kole C (ed) Genome mapping and molecular breeding in plants: pulses, sugar and tuber crops. Springer, Berlin, pp 33-47

McPhee KE, Inglis DA, Gunderson B, Coyne CJ (2012) Mapping a resistance gene for Fusarium wilt race 2 on LG IV of pea (Pisum sativum L.). Plant Breed 131:300-306

Menéndez CM, Hall AE, Gepts P (1997) A genetic linkage map of cowpea (Vigna unguiculata) developed from a cross between two inbred, domesticated lines. Theor Appl Genet 95:1210-1217

Meuwissen T (2007) Genomic selection: marker-assisted selection on a genome wide scale. J Anim Breed Genet 124:321-322

Meuwissen THE, Hayes BJ, Goddard ME (2001) Prediction of total genetic value using genome-wide dense marker maps. Genetics 157:1819-1829 
Mitchell-Olds T (2010) Complex-trait analysis in plants. Genome Biol 11:113

Muchero W, Diop NN, Bhat PR, Fenton RD, Wanamaker S, Pottorff M, Hearne S, Cisse N, Fatokun C, Ehlers JD, Roberts PA, Close TJ (2009a) A consensus genetic map of cowpea (Vigna unguiculata (L.) Walp.) and synteny based on EST-derived SNPs. Proc Natl Acad Sci USA 106:18159-18164

Muchero W, Ehlers JD, Close TJ, Roberts PA (2009b) Mapping QTL for drought stress-induced premature senescence and maturity in cowpea (Vigna unguiculata (L.) Walp.). Theor Appl Genet 118:849-863

Muchero W, Ehlers JD, Close TJ, Roberts PA (2011) Genic SNP markers and legume synteny reveal candidate genes underlying QTL for Macrophomina phaseolina resistance and maturity in cowpea (Vigna unguiculata (L.) Walp.). BMC Genom $12: 8$

Muchero W, Roberts PA, Diop NN, Drabo I, Cisse N, Close TJ, Muranaka S, Boukar O, Ehlers JD (2013) Genetic architecture of delayed senescence, biomass, and grain yield under drought stress in cowpea. PLoS One 8:e70041

Muehlbauer FJ, Cho S, Sarker A, McPhee KE, Coyne CJ, Rajesh PN, Ford R (2006) Application of biotechnology in breeding lentil for resistance to biotic and abiotic stress. Euphytica 147:149-165

Murray S, Falloon L, Frew T, Coyne CJ, Butler R, TimmermaVaughn G (2009) Association mapping of yield candidate gene homologs in a diverse collection of pea (Pisum sativum L.) lines. In: Meeting Proceedings, 19th annual queenstown molecular biology meetings 30 Aug-1st Sept

Nakaya A, Isobe SN (2012) Will genomic selection be a practical method for plant breeding? Ann Bot 110:1303-1316

Olhoft PM, Somers DA (2001) L-Cysteine increases Agrobacteriummediated T-DNA delivery into soybean cotyledonary-node cells. Plant Cell Rep 20:706-711

Omoigui LO, Yeye M, Ousmane B, Gowda BS, Timko MP (2012) Molecular characterization of cowpea breeding lines for striga resistance using SCAR markers. J Agric Sci Technol B 2(2012):362-367

Omo-Ikerodah EE, Fawole I, Fatokun CA (2008) Genetic mapping of quantitative trait loci (QTLs) with effects on resistance to flower bud thrips (Megalurothrips sjostedti) identified in recombinant inbred lines of cowpea. Afr J Biotechnol 7:263-270

Ouedraogo JT, Maheshwari V, Berner DK, Stpierre CA, Belzile F, Timko MP (2001) Identification of AFLP markers linked to resistance of cowpea (Vigna unguiculata L.) to parasitism by Striga gesnerioides. Theor Appl Genet 102:1029-1036

Ouedraogo JT, Gowda BS, Jean M, Close TJ, Ehlers JD, Hall AE, Gillaspie AG, Roberts PA, Ismail AM, Bruening G, Gepts P, Timko MP, Belzile FJ (2002) An improved genetic linkage map for cowpea (Vigna unguiculata L.) combining AFLP, RFLP, RAPD and biochemical markers. Genome 45:175-188

Ouedraogo JT, Ouedraogo M, Gowda BS, Timko MP (2012) Development of sequence characterized amplified region (SCAR) markers linked to race-specific resistance to Striga gesnerioides in cowpea (Vigna unguiculata L.). Afr J Biotechnol 11:12555-12562

Pereira G, Marques C, Ribeiro R, Formiga S, Dâmaso M, TavaresSousa M, Farinho M, Leitao JM (2010) Identification of DNA markers linked to an induced mutated gene conferring resistance to powdery mildew in pea (Pisum sativum L.). Euphytica 171:327-335

Pérez de la Vega M, Fratini RM, Muehlbauer FJ (2011) Lentil. In: Pérez de la Vega M, Torres AM, Cubero JI, Kole C (eds) Genetics, genomics and breeding of cool season grain legumes (genetics, genomics and breeding in crop plants). Science Pubs, New Hampshire, pp 98-150
Pilet-Nayel ML, Muehlbauer FJ, McGee RJ, Kraft JM, Baranger A, Coyne CJ (2002) Quantitative trait loci for partial resistance to Aphanomyces root rot in pea. Theor Appl Genet 106:28-39

Popelka JC, Terryn N, Higgins TJV (2004) Gene technology for grain legumes: can it contribute to the food challenge in developing countries? Plant Sci 167:195-206

Popelka JC, Gollasch S, Moore A, Molvig L, Higgins TJV (2006) Genetic transformation of cowpea (Vigna unguiculata L.) and stable transmission of the transgenes to progeny. Plant Cell Rep 25:304-312

Pottorff M, Ehlers JD, Fatokun C, Roberts PA, Close TJ (2012a) Leaf morphology in cowpea (Vigna unguiculata (L.) Walp.): QTL analysis, physical mapping and identifying a candidate gene using synteny with model legume species. BMC Genom 13:234

Pottorff M, Wanamaker S, Ma YQ, Ehlers JD, Roberts PA, Close TJ (2012b) Genetic and physical mapping of candidate genes for resistance to Fusarium oxysporum f. sp. tracheiphilum race 3 in cowpea (Vigna unguiculata (L.) Walp.). PLoS One 7(7):e41600

Pottorff MO, Li G, Ehlers JD, Close TJ, Roberts PA (2014) Genetic mapping, synteny, and physical location of two loci for Fusarium oxysporum f. sp. tracheiphilum race 4 resistance in cowpea [Vigna unguiculata (L.) Walp]. Mol Breed 33:79-791

Prioul S, Frankewitz A, Deniot G, Morin G, Baranger A (2004) Mapping of quantitative trait loci for partial resistance to Mycosphaerella pinodes in pea (Pisum sativum L.), at the seedling and adult plant stages. Theor Appl Genet 108:1322-1334

Rameau C, Dénoue D, Fraval F, Haurogné K, Josserand J, Laucou V, Batge S, Murfet IC (1998) Genetic mapping in pea. 2. Identification of RAPD and SCAR markers linked to genes affecting plant architecture. Theor Appl Genet 97:916-928

Ramsay L, Sharpe AG, Cook DR, Penmetsa RV, Gujaria Verma N, Vandenberg A, Bett K (2014) Draft genome assembly and survey of genetic diversity within Lens culinaris. In: Proceedings of plant and animal genome conference XXII W215 (https://pag .confex.com/pag/xxii/webprogram/Paper9440.html)

Ribaut JM, Ragot M (2007) Marker-assisted selection to improve drought adaptation in maize: the backcross approach, perspectives, limitations, and alternatives. J Exp Bot 58:351-360

Ribaut JM, de Vicente MC, Delannay X (2010) Molecular breeding in developing countries, challenges and perspectives. Curr Opin Plant Biol 13:213-218

Ribaut JM, Bertioli DJ, Raatz B, Roberts P, Vadez V, Varshney RK, Diop NN (2012) Innovative approaches to increase tropical legume productivity in Africa and South Asia. In: Proceedings of international conference on legume genetics and genomics (ICLGG) VI I-GAB01

Rodrigues MA, Santos CAF, Santana JRF (2012) Mapping of AFLP loci linked to tolerance to cowpea golden mosaic virus. Genet Mol Res 11:3789-3797

Román B, Torres AM, Rubiales D, Cubero JI, Satovic Z (2002) Mapping of quantitative trait loci controlling broomrape (Orobanche crenata Forsk) resistance in faba bean (Vicia faba L.). Genome 45:1057-1063

Román B, Satovic Z, Avila CM, Rubiales D, Moreno MT, Torres AM (2003) Locating genes associated with Ascochyta fabae resistance in Vicia faba L. Aust J Agric Res 54:85-90

Román B, Satovic Z, Pozarkova D, Macas J, Dolezel J, Cubero JI, Torres AM (2004) Development of a composite map in Vicia faba, breeding applications and future prospects. Theor Appl Genet 108:1079-1088

Rubeena, Ford R, Taylor PW (2003) Construction of an intraspecific linkage map of lentil (Lens culinaris ssp. culinaris). Theor Appl Genet 107:910-916

Rubeena, Taylor PW, Ades PK, Ford R (2006) QTL mapping of resistance in lentil (Lens culinaris ssp. culinaris) to Ascochyta blight (Ascochyta lentis). Plant Breed 125:506-512 
Rubiales D, Ferna'ndez-Aparicio M (2012) Innovations in parasitic weeds management in legume crops: a review. Agron Sustain Dev 32:433-449

Rubiales D, Ambrose MJ, Domoney C, Burstin J (2011) Pea (Pisum sativum L.). In: de la Vega MP, Torres AM, Cubero JI, Kole C (eds) Genetics, genomics and breeding of cool season grain legumes (genetics, genomics and breeding in crop plants). Science Pub, New Hampshire, pp 1-49

Saha GC, Sarker A, Chen W, Vandemark GJ, Muehlbauer FJ (2010) Inheritance and linkage map positions of genes conferring resistance to stemphylium blight in lentil. Crop Sci 50:1831-1839

Saha GC, Sarker A, Chen W, Vandemark GJ, Muehlbauer FJ (2013) Inheritance and linkage map positions of genes conferring agromorphological traits in Lens culinaris Medik. Intl J Agron 2013:618926

Satovic Z, Torres AM, Cubero JI (1996) Genetic mapping of new morphological, isozyme and RAPD markers in Vicia faba L. using trisomics. Theor Appl Genet 93:1130-1138

Satovic Z, Avila CM, Cruz-Izquierdo S, Díaz-Ruíz R, García-Ruíz GM, Palomino C, Gutiérrez N, Vitale S, Ocaña-Moral S, Gutiérrez MV, Cubero JI, Torres AM (2013) A reference consensus genetic map for molecular markers and economically important traits in faba bean (Vicia faba L.). BMC Genom 14:932

Sauerborn J, Saxena MC (1986) A review on agronomy in relation to Orobanche problems in faba bean (Vicia faba L.). In: ter Borg SJ (ed) Biology and control of Orobanche. Proceedings of a workshop on biology and control of Orobanche, Agricultural University Wageningen, The Netherlands, pp 160-165

Sax K (1923) The association of size differences with seed coat pattern and pigmentation in Phaseolus vulgaris. Genetics $8: 552-560$

Saxena KB (2008) Genetic improvement of pigeonpea: a review. Tropical Plant Biol 1:159-178

Saxena MC, Weigand S, Li-Juan L (eds) (1993) Faba bean production and research in China: In: Proceedings of an international symposium. Aleppo, ICARDA, pp 179

Saxena RK, Penmetsa RV, Upadhyaya HD, Kumar A, CarrasquillaGarcia N, Schlueter JA, Farmer A, Whaley AM, Sarma BK, May GD, Cook DR, Varshney RK (2012) Large-scale development of cost-effective single-nucleotide polymorphism marker assays for genetic mapping in pigeonpea and comparative mapping in legumes. DNA Res 19:449-461

Schmutz J, Cannon SB, Schlueter J et al (2010) Genome sequence of the paleopolyploid soybean. Nature 463:178-183

Schneider A, Walker SA, Sagan M, Duc G, Ellis THN, Downie JA (2002) Mapping of the nodulation loci sym 9 and sym10 of pea (Pisum sativum L.). Theor Appl Genet 104:1312-1316

Sever T, Ates D, Aldemir SB, Yagmur B, Kaya HB, Temel HY, Kahriman A, Ozkan H, Tanyolac MB (2014) Identification QTLs controlling genes to Se uptake in lentil seeds. In: Proceedings of plant and animal genome conference XXII P359 (https://pag.co nfex.com/pag/xxii/webprogram/Paper9688.html)

Sharpe AG, Ramsay L, Sanderson LA, Fedoruk MJ, Clarke WE, Li R, Kagale S, Vijayan P, Vandenberg A, Bett KE (2013) Ancient orphan crop joins modern era: gene-based SNP discovery and mapping in lentil. BMC Genom 14:192

Sindhu A, Marwan M, Bett K, Taran B, Sharpe AG, Ramsay LD, Warkentin T (2013) Development of a functional SNP map for pea and identification of markers linked to agronomic important traits. In: Proceedings of plant and animal genome conference XXI P0355 (https://pag.confex.com/pag/xxi/webprogram/ Paper6414.html)

Singh BB (2005) Cowpea (Vigna unguiculata (L.) Walp). In: Singh RJ, Jauhar PP (eds) Genetic resources, chromosome engineering and crop improvement, CRC Press, pp 117-162
Somers DA, Samac DA, Olhoft PM (2003) Recent advances in legume transformation. Plant Physiol 131:892-899

Svabova L, Griga M (2008) The effect of cocultivation treatments on transformation efficiency in pea (Pisum sativum L.). Plant Cell Tissue Organ Cult 95:293-304

Tadege M, Wang TL, Wen J, Ratet P, Mysore KS (2009) Mutagenesis and beyond! Tools for understanding legume biology. Plant Physiol 151:978-984

Tague BW, Mantis J (2006) In planta Agrobacterium-mediated transformation by vacuum infiltration. Methods Mol Biol 323:215-223

Tanksley SD, Nelson JC (1996) Advanced backcross QTL analysis: a method for the simultaneous discovery and transfer of valuable QTLs from unadapted germplasm into elite breeding lines. Theor Appl Genet 92:191-203

Tanyolac B, Ozatay S, Kahraman A, Muehlbauer F (2010) Linkage mapping of lentil (Lens culinaris L.) genome using recombinant inbred lines revealed by AFLP, ISSR, RAPD and some morphologic markers. J Agri Biotechnol Sust Develop 2:1-6

Tar'an B, Buchwaldt L, Tullu A, Banniza S, Warkentin TD, Vandenberg A (2003a) Using molecular markers to pyramid genes for resistance to ascochyta blight and anthracnose in lentil (Lens culinaris Medik). Euphytica 134:223-230

Tar' an B, Warkentin T, Somers DJ, Miranda D, Vandenberg A, Blade S, Woods S, Bing D, Xue A, DeKoeyer D, Penner G (2003b) Quantitative trait loci for lodging resistance, plant height and partial resistance to mycosphaerella blight in field pea (Pisum sativum L.). Theor Appl Genet 107:1482-1491

Tar' an B, Warkentin T, Somers DJ, Miranda D, Vandenberg A, Blade S, Woods S, Bing D (2004) Identification of quantitative trait loci for grain yield, seed protein concentration and maturity in field pea (Pisum sativum L.). Euphytica 136:297-306

Temel HY, Gol D, Kahriman A, Tanyolac MB (2014) Construction of linkage map through genotyping-by-sequencing in lentil. In: Proceedings of plant and animal genome conference XXII P358 (https://pag.confex.com/pag/xxii/webprogram/Paper10284.html)

Thudi M, Bohra A, Nayak SN et al (2011) Novel SSR markers from BAC-end sequences, DArT arrays and a comprehensive genetic map with 1,291 marker loci for chickpea (Cicer arietinum L.). PLoS One 6:e27275

Tian F, Bradbury PJ, Brown PJ, Hung H, Sun Q, Flint-Garcia S, Rocheford TR, McMullen MD, Holland JB, Buckler ES (2011) Genome-wide association study of leaf architecture in the maize nested association mapping population. Nat Genet 43:159-162

Timko MP, Ehlers JD, Roberts PA (2007) Cowpea. In: Kole C (ed) Genome mapping and molecular breeding in plants: pulses, sugar and tuber crops. Springer, Berlin, pp 49-67

Timmerman GM, Frew TJ, Miller AL, Weeden NF, Jermyn WA (1993) Linkage mapping of $s b m-1$, a gene conferring resistance to pea seed-borne mosaic virus, using molecular markers in Pisum sativum. Theor Appl Genet 85:609-615

Timmerman-Vaughan GM, McCallum JA, Frew TJ, Weeden NF, Russell AC (1996) Linkage mapping of quantitative trait loci controlling seed weight in pea (Pisum sativum L.). Theor Appl Genet 93:431-439

Timmerman-Vaughan GM, Frew TJ, Russell AC, Khan T, Butler R, Gilpin M, Murray S, Falloon K (2002) QTL mapping of partial resistance to field epidemics of ascochyta blight of pea. Crop Sci 42:2100-2111

Timmerman-Vaughan GM, Frew TJ, Butler R, Murray S, Gilpin M, Falloon K, Johnston P, Lakeman MB, Russell A, Khan T (2004) Validation of quantitative trait loci for Ascochyta blight resistance in pea (Pisum sativum L.), using populations from two crosses. Theor Appl Genet 109:1620-1631

Timmerman-Vaughan GM, Mills A, Whitfield C, Frew T, Butler R, Murray S, Lakeman M, McCallum J, Russell A, Wilson D 
(2005) Linkage mapping of QTL for seed yield, yield components, and development traits in pea. Crop Sci 45:1336-1344

Tiwari KR, Penner GA, Warkentin TD (1998) Identification of coupling and repulsion phase RAPD markers for powdery mildew resistance gene $e r-1$ in pea. Genome 41:440-444

Tonguç M, Weeden NF (2010) Identification and mapping of molecular markers linked to erl gene in pea. J Plant Mol Biol Biotechnol 1:1-5

Torres AM, Román B, Avila CM, Satovic Z, Rubiales D, Sillero JC, Cubero JI, Moreno MT (2006) Faba bean breeding for resistance against biotic stresses: towards application of marker technology. Euphytica 147:67-80

Torres AM, Avila CM, Gutiérrez N, Palomino C, Moreno MT, Cubero JI (2010) Marker-assisted selection in faba bean (Vicia faba L.). Field Crop Res 115:243-252

Torres AM, Avila CM, Stoddard FL, Cubero JI (2011) Faba bean. In: Pérez de la Vega M, Torres AM, Cubero JI, Kole C (eds) Genetics, genomics and breeding of cool season grain legumes (genetics, genomics and breeding in crop plants). Science Pubs, New Hampshire, pp 50-97

Triques K, Sturbois B, Gallais S, Dalmais M, Chauvin S, Clepet C, Aubourg S, Rameau C, Caboche M, Bendahmane A (2007) Characterization of Arabidopsis thaliana mismatch specific endonucleases: application to mutation discovery by TILLING in pea. Plant J 51:1116-1125

Tullu A, Buchwaldt T, Warkentin T, Tar'an B, Vandenberg A (2003) Genetics of resistance to anthracnose and identification of AFLP and RAPD markers linked to the resistance gene in PI 320937 germplasm of lentil (Lens culinaris Medikus). Theor Appl Genet 106:428-434

Tullu A, Tar'an B, Breitkreutz C, Buchwaldt L, Banniza S, Warkentin TD, Vandenberg A (2006) A quantitative trait locus for resistance to ascochyta blight (Ascochyta lentis) maps close to a gene for resistance to anthracnose (Colletotrichum truncatum). Can J Plant Pathol 28:588-595

Tullu A, Tar' an B, Warkentin T, Vandenberg A (2008) Construction of an intraspecific linkage map and QTL analysis for earliness and plant height in lentil. Crop Sci 48:2254-2264

Ubayasena L, Bett K, Tar'an B, Vijayan P, Warkentin TD (2010) Genetic control and QTL mapping of cotyledon bleaching resistance in green field pea (Pisum sativum L.). Genome $53: 346-359$

Ufaz S, Galili G (2008) Improving the content of essential amino acids in crop plants: goals and opportunities. Plant Physiol 147:954-961

Varshney RK, Close TJ, Singh NK, Hoisington DA, Cook DR (2009a) Orphan legume crops enter the genomics era! Curr Opin Plant Biol 12:202-210

Varshney RK, Nayak SN, May GD, Jackson SA (2009b) Next-generation sequencing technologies and their implications for crop genetics and breeding. Trends Biotechnol 27:522-530

Varshney RK, Hoisington DA, Nayak SN, Graner A (2009c) Molecular plant breeding: methodology and achievements. In: Somers D, Langridge P, Gustafson PJ (eds) Plant genomics: methods and protocols. The Humana Press, Totowa, pp 283-304

Varshney RK, Glaszmann JC, Leung H, Ribaut JM (2010) More genomic resources for less-studied crops. Trends Biotechnol 28:452-460

Varshney RK, Chen W, Li Y et al (2011) Draft genome sequence of pigeonpea (Cajanus cajan), an orphan legume crop of resourcepoor farmers. Nat Biotechnol 30:83-89

Varshney RK, Ribaut JM, Buckler ES, Tuberosa R, Rafalski JA, Langridge P (2012) Can genomics boost productivity of orphan crops. Nat Biotechnol 30:1172-1176

Varshney RK, Murali Mohan S, Gaur PM et al (2013a) Achievements and prospects of genomics-assisted breeding in three legume crops of the semi-arid tropics. Biotechnol Adv 31:1120-1134
Varshney RK, Song C, Saxena RK et al (2013b) Draft genome sequence of chickpea (Cicer arietinum) provides a resource for trait improvement. Nat Biotechnol 31:240-246

Vaz Patto MC, Torres AM, Koblizkova A, Macas J, Cubero JI (1999) Development of a genetic composite map of Vicia faba using $\mathrm{F}_{2}$ populations derived from trisomic plants. Theor Appl Genet 98:736-743

Venter JC, Smith HO, Hood L (1996) A new strategy for genome sequencing. Nature 381:364-366

Verma P, Shah N, Bhatia S (2013) Development of an expressed gene catalogue and molecular markers from the de novo assembly of short sequence reads of the lentil (Lens culinaris Medik.) transcriptome. Plant Biotechnol J 11:894-905

Von Stackelberg M, Lindemann S, Menke M, Riesslemann S, Jacobsen HJ (2003) Identification of AFLP and STS markers closely linked to def locus in pea. Theor Appl Genet 106:1293-1299

Wale M (2002) Population dynamics of the pea aphid, Acyrthosiphon pisum (Harris) (Homoptera: Aphididae) on field pea (Pisum sativum L.) in Northwestern Ethiopia. Insect Sci Applic 22:131-137

Weeden NF (2007) Genetic changes accompanying the domestication of Pisum sativum: is there a common genetic basis to the 'domestication syndrome' for legumes? Ann Bot 100:1017-1025

Weeden NF, Ellis THN, Timmerman-Vaughan GM, Swiecicki WK, Rozov SM, Berdnikov VA (1998) A consensus linkage map for Pisum sativum. Pisum Genet 30:1-4

Weeks JT, Ye J, Rommens CM (2008) Development of an in planta method for transformation of alfalfa (Medicago sativa). Transgenic Res 17:587-597

Xu P, Wu XH, Wang BG et al (2010) Development and polymorphism of Vigna unguiculata ssp. unguiculata microsatellite markers used for phylogenetic analysis in asparagus bean (Vigna unguiculata ssp. sesquipedialis (L.) Verdc.). Mol Breed 25:675-684

Xu P, Wu XH, Wang BG, Liu YH, Ehlers JD, Close TJ (2011a) A SNP and SSR based genetic map of asparagus bean (Vigna. unguiculata ssp. sesquipedialis) and comparison with the broader species. PLoS One 6:1-8

Xu P, Hu T, Yang Y, Wu X, Wang B, Liu Y, Qin D, Ehlers JD, Close TC, Lu Z, Li G (2011b) Mapping genes governing flower and seed coat color in asparagus bean (Vigna unguiculata ssp sesquipedalis) based on SNP and SSR markers. Hort Sci 46:1102-1104

Xu P, Wu XH, Wang BG, Luo J, Liu YH, Ehlers JD, Close TJ, Philip RA, Lu ZF, Wang S, Li GJ (2012a) Genome wide linkage disequilibrium in Chinese asparagus bean (Vigna unguiculata ssp. sesquipedialis) germplasm: implications for domestication history and genome wide association studies. Heredity 109:34-40

Xu Y, Lu Y, Xie C, Gao S, Wan J, Prasanna BM (2012b) Wholegenome strategies for marker-assisted plant breeding. Mol Breed 29:833-854

Xu P, Wu X, Wang B, Hu T, Lu Z, Liu Y, Qin D, Wang S, Li G (2013) QTL mapping and epistatic interaction analysis in asparagus bean for several characterized and novel horticulturally important traits. BMC Genet 14:4

Xue AG, Warkentin TD, Kenaschuk EO (1997) Effect of timings of inoculation with Mycosphaerella pinodes on yield and seed infection on field pea. Can J Plant Sci 77:685-689

Yang T, Bao SY, Ford R, Jia TJ, Guan JP, He YH, Sun XL, Jiang JY, Hao JJ, Zhang XY, Zong XX (2012) High-throughput novel microsatellite marker of faba bean via next generation sequencing. BMC Genom 13:602-613

Yang H, Tao Y, Zheng Z, Zhang Q, Zhou G, Sweetingham MW, Howieson JG, Li C (2013) Draft genome sequence, and a sequencedefined genetic linkage map of the legume crop species Lupinus angustifolius L. PLoS One 8:e64799 
Young ND, Mudge J, Noel Ellis TH (2003) Legume genomes: more than peas in a pod. Curr Opin Plant Biol 6:199-204

Young ND, Debellé F, Oldroyd GE et al (2011) The Medicago genome provides insight into the evolution of rhizobial symbioses. Nature 480:520-524

Yu K (2012) Bacterial artificial chromosome libraries of pulse crops: characteristics and applications. J Biomed Biotech 2012:493186. doi:10.1155/2012/493186

Yu J, Buckler ES (2006) Genetic association mapping and genome organization of maize. Curr Opin Plant Biol 17:155-160

Zamir D, Ladizinsky G (1984) Genetics of allozyme variants and linkage groups in lentil. Euphytica 33:329-336
Zeid M, Mitchell S, Link W, Carter M, Nawar A, Fulton T, Kresovich S (2009) Simple sequence repeats (SSRs) in faba bean: new loci from Orobanche-resistant cultivar 'Giza 402'. Plant Breed 128:149-155

Zhu H, Choi HK, Cook DR, Shoemaker RC (2005) Bridging model and crop legumes through comparative genomics. Plant Physiol 137:1189-1196

Zohary D, Hopf M (2000) Domestication of plants in the old world, 3rd edn. Clarendon Press, Oxford 